\title{
Effect of frozen and refrigerated storage on proteolysis and physicochemical properties of high-moisture citric mozzarella cheese
}

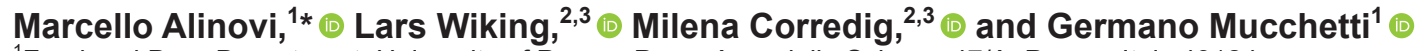 \\ ${ }^{1}$ Food and Drug Department, University of Parma, Parco Area delle Scienze 47/A, Parma, Italy 43124 \\ ${ }^{2}$ Department of Food Science, Aarhus University, Agro Food Park 48, Skejby, Denmark 8200 \\ ${ }_{3}$ iFood Center, Department of Food Science, Aarhus University, Agro Food Park 48, Skejby, Denmark 8200
}

\section{ABSTRACT}

High-moisture mozzarella is one of the most-exported Italian cheeses worldwide, but its quality is affected by storage. Freezing is regarded as a solution to decrease product waste, extend market reach, and increase convenience, but its effect on quality has to be estimated. In this study, the details related to proteolysis, physicochemical properties, and sensory quality parameters of high-moisture mozzarella as a function of frozen storage $(1,3$, and $4 \mathrm{mo})$ and subsequent refrigerated storage after thawing $(1,3$, and $8 \mathrm{~d})$ were evaluated. Frozen cheeses stored at $-18^{\circ} \mathrm{C}$ showed a higher extent of proteolysis, as well as different colorimetric and sensory properties, compared with the fresh, nonfrozen control. Sensory evaluation showed the emergence of oxidized and bitter taste after 1 mo of frozen storage, which supports the proteolysis data. The extent of proteolysis of frozen-stored cheese after thawing was greater than that measured in fresh cheese during refrigerated storage. These results help better understand the changes occurring during frozen storage of high-moisture mozzarella cheese and evaluate possible means to decrease the effect of freezing on the cheese matrix.

Key words: frozen storage, mozzarella cheese, proteolysis, oxidation

\section{INTRODUCTION}

High-moisture (HM) mozzarella is one of the mostconsumed Italian-type cheeses worldwide. This product is different from the low-moisture (LM) mozzarella used, for example, as an ingredient for food preparations (e.g., pizza, baked products). High-moisture mozzarella usually contains 55 to $65 \%$ moisture, and it is usually

Received February 19, 2020.

Accepted April 27, 2020.

*Corresponding author: marcello.alinovi@studenti.unipr.it consumed as a fresh cheese. To prevent rind formation and moisture loss, HM mozzarella is often stored in a brine. Italian HM mozzarella cheese is manufactured by lactic acid fermentation with Streptococcus thermophilus cultures or by direct acidification using a solution of organic acids (e.g., citric acid, lactic acid) (Mucchetti et al., 2017).

Italian exportation of HM mozzarella cheese has increased in the past decade. In 2017, Italy produced 313,700 tons of HM mozzarella, of which 85,136 tons were exported (Assolatte, 2018). More than $30 \%$ of the total export was marketed in nonEuropean countries. Furthermore, with the increase in consumer awareness for this type of product, HM mozzarella demand is growing in regions characterized by scarcity of milk (e.g., countries in Asia and the Middle East; CLAL, 2020).

Because of its high moisture and fresh taste expected by the consumer, HM mozzarella cheese is characterized by poor storability. Its relatively short shelf life, ranging from 1 to $30 \mathrm{~d}$ (Mucchetti et al., 2017), presents a challenge for the supply chain and results in product waste. Within the shelf life, quality properties of fresh mozzarella cheese change as a consequence of proteolysis and exchange of matter with the covering liquid (Faccia et al., 2019).

Fresh mozzarella cheese needs to be transported rapidly (e.g., air transport) with robust cold chain controls, and slower means of transportation (e.g., sea transport) are not suitable to reach long-distance markets. However, considering the high costs and large environmental footprint of air transport (Dalla Riva et al., 2017), sea transport would be preferred. In this context, freezing and frozen storage of HM mozzarella is a preferred solution to improve storability of the product, decrease waste, and create a more sustainable supply chain (Tejada et al., 2000; Alvarenga et al., 2013).

The freezing process of HM mozzarella cheese is currently applied in industrial scale for export worldwide using various technologies, including individual quick freezing (Zambrini and Bernardi, 2017). Conte et al. 
(2017) compared the effects of freezing rate and frozen storage of HM mozzarella and highlighted a decrease of pores volume and overall sensory quality with decreasing cheese size and with increasing freezing rate. Alinovi and Mucchetti (2020) showed an important effect of the presence or absence of covering liquid during freezing on mozzarella's physical and sensory characteristics; however, freezing and thawing rates (from -25 to $-40^{\circ} \mathrm{C}$ with different air velocities) did not affect those characteristics. The application of frozen storage has been largely assessed in the case of LM mozzarella cheese (Diefes et al., 1993; Ribero et al., 2007, 2009).

Frozen storage can have the following effects on cheese characteristics: it can cause the rupture of the casein matrix as a consequence of ice crystal formation (Graiver et al., 2004; Kuo and Gunasekaran, 2009); it can promote protein dehydration, which affects texture and rheological properties (Diefes et al., 1993); and it can ultimately modify the sensory perception of the cheese (Park et al., 2006). A better understanding of the decrease in quality parameters during freezing and storage is necessary to identify the critical points affecting quality and to better design, monitor, and tailor the process of cheese making and subsequent freezing and storage.

Frozen storage causes changes in water activity $\left(\mathbf{a}_{\mathrm{w}}\right)$. At a temperature of $-20^{\circ} \mathrm{C}, \mathrm{a}_{\mathrm{w}}$ is about 0.82 , assuming it is in the range between the freezing point and the eutectic point of the solution and considering the hypothetical standard state of pure liquid water (Troller and Christian, 1978; Fontana, 2007). In this condition, chemical changes in foods are slowed down, and microbial viability is strongly reduced (Troller and Christian, 1978); however, some enzymatic residual activities can still be present, even at relatively low $\mathrm{a}_{\mathrm{w}}$ and temperatures (Schmidt, 2007), namely, proteolysis, lipolysis, and oxidation. Moreover, it is possible that after thawing, the rate of enzymatic reactions may increase as a consequence of ice crystal damage, casein supramolecular structure modifications, or the liberation of enzymes from microbial cells (Verdini et al., 2005; Alvarenga et al., 2011).

The objective of this work was to evaluate the effects of frozen storage and subsequent refrigerated storage after thawing on HM Italian citric mozzarella cheese characteristics, to assess the applicability of the freezing process to extend the shelf life of this product, and to highlight critical factors promoting quality changes of the cheese. By using citric acid mozzarella, it was possible to eliminate the potential effect of the proteolysis caused by the lactic acid bacterial cultures in the cheese.

\section{MATERIALS AND METHODS}

\section{Experimental Design}

Experimental trials were organized according to a complete block design. Three batches of HM mozzarella were used (i.e., cheeses manufactured on different days by the same dairy). For each batch, assumed as the blocking factor of the design, 45 cheeses were frozen in 3 separate freezing runs ( 15 cheeses were frozen for each run). To evaluate the effect of the frozen storage on mozzarella cheese characteristics, a group of 15 cheeses from each batch was thawed at 1, 3, or 4 mo of storage.

Moreover, to study the effect of refrigerated storage $\left(4^{\circ} \mathrm{C}\right)$, frozen-thawed cheeses were analyzed during the subsequent refrigerated storage; each group of 15 thawed cheeses was subdivided into 3 groups $(\mathrm{n}=5)$, which were analyzed at 1,3 , or $8 \mathrm{~d}$ after thawing. For each batch, a control sample of fresh, nonfrozen cheese (identified as 0 mo of frozen storage) was tested after 1,3 , and $8 \mathrm{~d}$ of storage at $4^{\circ} \mathrm{C}$, for comparison with the frozen-thawed samples.

\section{Freezing Conditions and Experiments}

Three batches of fresh, HM mozzarella cheese were industrially manufactured by Alival S.p.a. (Nuova Castelli S.p.a. RE, Reggio Emilia, Italy) according to the manufacturing method reported by Francolino et al. (2010). The cheeses used for the study were produced on different days in a 2-mo period using standardized cow's milk $(3.30 \mathrm{~g} / 100 \mathrm{~g}$ of protein, $3.50 \mathrm{~g} / 100 \mathrm{~g}$ of fat). In brief, milk was pasteurized at $74^{\circ} \mathrm{C}$ for $25 \mathrm{~s} ; 1.2$ $\mathrm{g} / 100 \mathrm{~g}$ of citric acid and microbial rennet were added to start milk coagulation. Cheese curd stretching was carried out with salted boiling water $\left(87.5 \pm 2.5^{\circ} \mathrm{C}\right)$ by using a dipping arms cooker/stretcher; cheeses were mechanically molded into individual balls $(100 \pm 1 \mathrm{~g})$ using a rotary molding machine and were cooled by immersion into tap water. Each cheese was characterized by a nonregular spheroidal shape with a nonconstant diameter of approximately 4 to $6 \mathrm{~cm}$. Cheeses were individually packaged into polyethylene bags containing $100 \mathrm{~g}$ of covering liquid $(0.4 \mathrm{~g} / 100 \mathrm{~g} \% \mathrm{wt} /$ wt $\mathrm{NaCl})$. The product's final gross composition was $61 \mathrm{~g}$ of moisture, $18.0 \mathrm{~g}$ of protein, $17.0 \mathrm{~g}$ of fat, $1.0 \mathrm{~g}$ of lactose, and $0.4 \mathrm{~g}$ of $\mathrm{NaCl}$. All packaged cheeses were kept at $4 \pm 1^{\circ} \mathrm{C}$ for $6 \mathrm{~d}$ before being frozen or further kept in refrigerated storage (in the case of fresh, nonfrozen treatments).

Samples were frozen using an air blast freezer (MF 25.1, Irinox, TV, Italy), using an air temperature of 
$-25^{\circ} \mathrm{C}$ and a velocity of $1.3 \pm 0.2 \mathrm{~m} / \mathrm{s}$. These conditions were chosen because they did not show a strong effect on cheese quality characteristics (Alinovi and Mucchetti, 2020). Samples were separated from the covering liquid before freezing, and a temperature of $-20^{\circ} \mathrm{C}$ was reached in the core of the cheese after $67 \pm$ 3 min. After freezing, cheeses were immediately vacuum packaged into polyethylene bags and stored at $-18^{\circ} \mathrm{C}$.

After reaching the predefined storage times $(1,3$, or $4 \mathrm{mo}$ ), samples were thawed in the air blast cooler by applying an air temperature of $+4^{\circ} \mathrm{C}$, and a velocity of $1.3 \pm 0.2 \mathrm{~m} / \mathrm{s}$; thawing conditions were chosen because they did not show differences in cheese quality characteristics (rheological, textural, and sensory characteristics) compared with faster thawing conditions (Alinovi and Mucchetti, 2020). After thawing (309 \pm $18 \mathrm{~min}$ ), cheeses were immersed into $100 \mathrm{~mL}$ of freshly prepared covering liquid with the same composition of the original one, then refrigerated $\left(4 \pm 1^{\circ} \mathrm{C}\right)$. Before being analyzed, samples were taken out of the refrigerator and were equilibrated in a climate chamber (model ICH 256L, Memmert, Schwabach, Germany) at $25.0 \pm$ $0.1^{\circ} \mathrm{C}$ for $1 \mathrm{~h}$.

\section{Physical and Chemical Analyses}

Moisture content of the cheese was measured in triplicate according to AOAC (1990), whereas protein content of mozzarella cheese was determined using a Tango near-infrared spectrometer (Bruker, Billerica, MA) calibrated according to the manufacturer's instructions.

Colorimetric coordinates of the cheese were measured using a CR-2600d spectrophotometer (Minolta Co., Osaka, Japan) according to CIE L*a*b* color space. Lightness of color $\left(\mathbf{L}^{*}\right)$, redness $\left(\mathbf{a}^{*}\right)$, and yellowness $\left(\mathbf{b}^{*}\right)$ were measured in the internal and external part of the cheese in 5 different areas of the same sample.

\section{Protein Profiling and Proteolysis Analyses}

Sample Preparation. Samples at various storage times were freeze-dried (Freeze dryer Lio-5P, 5Pascal, Milano, Italy) and stored at $-20^{\circ} \mathrm{C}$ until analysis. Then, freeze-dried samples were finely ground using a mortar; $5 \mathrm{~g}$ of sample were resuspended in $50 \mathrm{~mL}$ of sodium citrate $68 \mathrm{mM}$ (Sigma Aldrich, Taufkirchen, Germany) for fluorescamine assay, and $1 \mathrm{~g}$ of sample was resuspended in $20 \mathrm{~mL}$ of sodium citrate $68 \mathrm{mM}$ for electrophoresis analyses and reverse-phase HPLC. Resuspension was performed by mixing the samples using a laboratory homogenizer (Ultraturrax T25, IKA, Staufen, Germany) at 14,000 rpm for $4 \mathrm{~min}$. To ensure complete rehydration, samples were mixed with a mag- netic stirrer at $50^{\circ} \mathrm{C}$ for $1 \mathrm{~h}$ as reported in the literature (Voutsinas et al., 1995a). Samples were then skimmed by performing a double centrifugation procedure at $3,000 \times g$ for $30 \mathrm{~min}$ at $4^{\circ} \mathrm{C}$ using a benchtop centrifuge (Heraeus multifuge 3 S-R, Hanau, Germany).

Reverse-Phase HPLC. Reverse-phase HPLC was performed as described by Jensen et al. (2012). Aliquots $(200 \mu \mathrm{L})$ of cheese extracts with an approximate protein concentration of $2.5 \mathrm{~g} / 100 \mathrm{~mL}$ were mixed with $600 \mu \mathrm{L}$ of a solution containing $6 \mathrm{M}$ guanidine hydrochloride and Bis-Tris buffer pH 7 (100 mM; Sigma Aldrich), and reduced with $19.5 \mathrm{~m} M$ dithioerythritol (Sigma Aldrich). Samples were kept at $37^{\circ} \mathrm{C}$ for $1 \mathrm{~h}$, centrifuged at $20,000 \times g$ for $10 \mathrm{~min}$ at $7^{\circ} \mathrm{C}$, and filtered through a $0.45-\mu \mathrm{m}$ polytetrafluoroethylene filter (MiniUniprep, Whatman, Florham Park, NJ ).

The analyses were performed using an Agilent LC 1100 series instrument (Agilent Technologies, Santa Clara, CA) equipped with a binary pump, including degasser, a vial sampler, a column thermostat, and a UV diode array detector (G1315A). Samples $(6 \mu \mathrm{L})$ were injected into a Jupiter C4 column $(250 \times 2 \mathrm{~mm}, 5-\mu \mathrm{m}$ particle size, $300 \AA$ pore size; Phenomenex, Torrance, CA), that separated casein at a controlled temperature of $40^{\circ} \mathrm{C}$. Elutions were carried out using a gradient consisting of solvent A, Milli-Q water with $0.05 \%$ ( $\mathrm{vol} /$ vol) trifluoroacetic acid (Sigma Aldrich), and solvent B acetonitrile (Merck, Darmstadt, Germany) with $0.05 \%$ (vol/vol) trifluoroacetic acid. The gradient was started at $33 \%$ of solvent B and increased up to $50 \%$ in $25 \mathrm{~min}$.

Caseins were detected and quantified by UV absorbance at $214 \mathrm{~nm}$. Data analysis was conducted using ChemStation software (Agilent Technologies). Peaks identification was made by comparing retention times with data reported in literature; relative quantification of the casein and degradation products was made by integrating peak areas and comparing with the total integrated peak area within each chromatogram. The relative protein content was calculated as the integrated peak area of a certain compound. All samples were analyzed in duplicate.

Polyacrylamide Gel Electrophoresis Analyses. Urea PAGE was performed according to Andrews (1983) and Sharma Khanal et al. (2019) using Novex TBE-Urea precast gels (15\% total acrylamide; Invitrogen, Carlsbad, CA). Sample solutions were mixed with the sample buffer $(89 \mathrm{~m} M$ Tris, $89 \mathrm{~m} M$ boric acid, 2 $\mathrm{m} M$ EDTA, $\mathrm{pH}$ 8.0, $12 \%$ Ficoll, $0.01 \%$ bromophenol blue, $0.02 \%$ xylene cyanole, $7 M$ urea; Invitrogen) in a 1:2 ratio. The solutions were heated at $95^{\circ} \mathrm{C}$ for $5 \mathrm{~min}$, and then approximately $5 \mu \mathrm{g}$ of proteins was loaded into separate wells of the gel. Gels were run at $180 \mathrm{~V}$ in an XCell electrophoresis system (Novex, Invitrogen). 
The SDS PAGE was performed using Mini-PROTEAN TGX precast gels (4-15\% acrylamide) that were run on a Mini-Protean II cube (Bio-Rad, Hercules, CA). Samples were diluted in a 1:2 ratio with Laemmli sample buffer (Laemmli, 1970) and were subsequently heated at $95^{\circ} \mathrm{C}$ for $5 \mathrm{~min}$. Gels were run in nonreducing conditions at $150 \mathrm{~V}$ by loading approximately $5 \mu \mathrm{g}$ of proteins in each well.

All urea and SDS PAGE gels were stained with Coomassie Brilliant Blue G250 (Sigma Aldrich) according to Blakesley and Boezi (1977), destained in several changes of distilled water, and scanned using ChemiDoc XRS+ (Bio-Rad). Densitometric analysis was performed using the associated image analysis software (Image Lab v. 5.2.1, Bio-Rad).

Quantification of Free Amino Terminals by Fluorescamine Assay. Fluorescamine assay was performed according to Dalsgaard et al. (2007) to estimate the formation of peptides and free amino acids by measuring primary amino groups (free $\mathrm{N}$-terminals and lysine side chains) in the samples.

Cheese solutions $(5 \mathrm{~mL})$ were mixed with an equal volume of $24 \%$ trichloroacetic acid (Merck) in a falcon tube, and proteins contained in the samples were precipitated at $0^{\circ} \mathrm{C}$ in ice for $1 \mathrm{~h}$. After precipitation, samples were centrifuged at $15,800 \times g$ and $4^{\circ} \mathrm{C}$ for 10 min in 2-mL Eppendorf tubes; $37 \mu \mathrm{L}$ of supernatant was mixed with $900 \mu \mathrm{L}$ of $0.1 \mathrm{M}$ sodium borate $\left(\mathrm{Na}_{2} \mathrm{~B}_{4} \mathrm{O}_{7}\right.$, $10 \mathrm{H}_{2} \mathrm{O}$ ) buffer $\mathrm{pH} 8.0$ (Sigma Aldrich). The resulting solutions were then mixed with $300 \mu \mathrm{L}$ of $0.2 \mathrm{mg} / \mathrm{mL}$ fluorescamine (Sigma Aldrich) in dried acetone; finally, $250 \mu \mathrm{L}$ of the obtained solutions were transferred to 96-well white opaque polystyrene plate (Costar 3912, Corning, NY), incubated for 18 min at room temperature, and measured in quadruplicate by fluorescence spectroscopy using a multimode microplate reader (Synergy 2, BioTek, Winooski, VT) using an excitation wavelength of $390 \mathrm{~nm}$ and fluorescence emission at $480 \mathrm{~nm}$. The extent of proteolysis was quantified as L-leucine equivalents $(\mathrm{m} M)$ using a L-leucine (Sigma Aldrich) standard curve (0.1-3.0 $\mathrm{mM}$ ).

\section{Rheological Analysis}

Rheological measurements were performed at a controlled temperature of $25.0 \pm 0.1^{\circ} \mathrm{C}$ using an ARES rheometer (TA instruments, New Castle, DE); the instrument was equipped with a $25-\mathrm{mm}$ parallel plate geometry with sandpaper to avoid sample slippage and a solvent trap to avoid moisture loss.

Analyses were performed in quadruplicate as previously reported (Alinovi et al., 2018a), with slight modifications. Disk-shape samples (4 $\mathrm{mm}$ in thickness, $30 \mathrm{~mm}$ in diameter) were gently portioned from the central part of mozzarella cheese using a slicer and a borer. Frequency sweep tests were performed within the linear viscoelastic region using a $0.05 \%$ constant strain. The frequency dependence of storage modulus $\left(G^{\prime}\right)$, loss modulus $\left(G^{\prime \prime}\right)$, and complex viscosity $\left(\eta^{*}\right)$ were evaluated using power law equations (Steffe, 1996; Sharma et al., 2016):

$$
\begin{aligned}
\mathrm{G}^{\prime} & =\mathrm{G}^{\prime}{ }_{1 \mathrm{~Hz}}(f)^{\mathrm{n}^{\prime}}, \\
\mathrm{G}^{\prime \prime} & =\mathrm{G}^{\prime \prime}{ }_{1 \mathrm{~Hz}}(f)^{\mathrm{n}^{\prime \prime}}, \\
\eta^{*} & =\eta^{*}{ }_{1 \mathrm{~Hz}}(f)^{\mathrm{n}^{*}-1} .
\end{aligned}
$$

\section{Descriptive Sensory Analysis}

Quantitative descriptive analysis was performed by 5 trained panelists (3 men, 2 women) according to Alinovi and Mucchetti (2020). Panelists had previous experience with descriptive sensory analysis of mozzarella cheese. Evaluated sensory descriptors were hardness, whiteness, bitterness, and oxidized notes. The intensity of every descriptor was evaluated between 1 (absence of the attribute) and 9 (extreme intensity of the attribute). Cheeses were portioned in 10-mm cubes for taste and aroma evaluation, and a half-portion of the cheeses was used for visual evaluation.

\section{Statistical Analysis}

To evaluate the main effect of frozen storage $\left(F t_{i}\right.$, $i=0,1,3$, or $4 \mathrm{mo}$, with 0 mo corresponding to the fresh, control cheese), and refrigerated storage $\left(R t_{k}, k\right.$ $=1,3$, or $8 \mathrm{~d}$ ) and the significance of their interactions, split-plot ANOVA models were created for all the parameters evaluated using PRC GLM of SAS (SAS Inst. Inc., Cary, NC) according to Alinovi et al. (2018b). Batch of cheese $\left(B_{j}, j=1,2\right.$, or 3$)$ was used as the blocking factor of the models (Equation 4):

$$
\begin{aligned}
Y_{i j k l}= & \mu+F t_{i}+B_{j}+\delta_{i j}+R t_{k} \\
& +(F t \times R t)_{i k}+\gamma_{i j k},
\end{aligned}
$$

where $\mu$ is the intercept of the model; $\delta_{i j}$ and $\gamma_{i j k}$ are the main plot and subplot error terms, respectively; and $Y_{i j k l}$ is the selected response variable. Post hoc tests were performed by Tukey's honest significant differences test $(\alpha=0.05)$ when significant main effects and interactions were found.

Principal component analysis (PCA) was also performed on the quality parameters. Before analysis, variables were normalized. Pearson correlation coeffi- 
Table 1. Moisture and protein content of mozzarella cheeses as a function of the different frozen storage times ${ }^{1}$

\begin{tabular}{lcc}
\hline $\begin{array}{l}\text { Frozen storage } \\
(\mathrm{mo})\end{array}$ & $\begin{array}{c}\text { Moisture } \\
(\% \mathrm{wt} / \mathrm{wt})\end{array}$ & $\begin{array}{c}\text { Protein } \\
(\% \mathrm{wt} / \mathrm{wt})\end{array}$ \\
\hline 0 & $61.1 \pm 2.6$ & $18.3 \pm 1.5$ \\
1 & $61.3 \pm 2.6$ & $17.5 \pm 1.1$ \\
3 & $60.8 \pm 2.5$ & $17.8 \pm 1.2$ \\
4 & $60.2 \pm 1.6$ & $18.5 \pm 1.1$ \\
\hline
\end{tabular}

${ }^{1} 0 \mathrm{mo}=$ fresh, nonfrozen cheese; reported as means $( \pm \mathrm{SD})$ of all refrigerated storage times.

cients (r) were also calculated to find relations among evaluated variables. Multivariate analysis and correlations among variables were performed using SPSS v. 25 (IBM, Armonk, NY).

\section{RESULTS AND DISCUSSION}

\section{Physical and Chemical Characteristics}

High-moisture mozzarella cheese chemical composition (Table 1) showed about $60 \%$ moisture and $18 \%$ protein and was not influenced by frozen storage $(P$ $>0.05$; Supplemental Table S1, https://doi.org/10 $.3168 /$ jds.2020-18396). In accordance to the results of a previous study (Alinovi and Mucchetti, 2020), a decrease in weight was observed consequently to freezing and thawing (about $-2.5 \%$ of the original weight), as during the processes the cheeses were not vacuumpacked; however, after the frozen-thawed cheeses were immersed overnight in new covering liquid (at $4^{\circ} \mathrm{C}$ ), they regained to approximately their original weight (Alinovi and Mucchetti, 2020). As a consequence of this phenomenon, the values of moisture and protein did not change with frozen storage (Table 1). This was expected, as a sample's vacuum package would avoid ice sublimation during frozen storage. In addition, no significant variation of the chemical composition $(P>$ $0.05)$ was found with refrigerated storage. It is impor- tant to point out that there was a significant $(P<0.05)$ batch-to-batch variation, which was considered in the statistical analysis (Supplemental Table S1, https://doi .org/10.3168/jds.2020-18396). This variation could be attributed to slight changes in milk characteristics and cheese making parameters that can be encountered in industrial processes.

Table 2 summarizes color variations as a function of frozen storage. Refrigerated storage did not show a significant effect for colorimetric parameters, with the only exception of $a^{*}$ in the inner part of the cheese that showed a significant $(P<0.05)$ but small increase $(<0.1)$ after $8 \mathrm{~d}$ of refrigerated storage (results not shown). In general, mozzarella cheese exhibited a high $\mathrm{L}^{*}$ value and a dominant yellow color, which were higher in the external part of the cheese and lower in the internal part, as previously reported (Alinovi and Mucchetti, 2020).

Lightness $\left(\mathrm{L}^{*}\right)$ showed a significant decrease with frozen storage times, both in the inner and in the outer part of the cheese $(P<0.05)$. This decrease of $\mathrm{L}^{*}$ (Table 2) may be caused by mesoscopic or microscopic structural reorganization of the matrix during frozen storage, and by differences in the amount and distribution of free water on the analyzed surface (SánchezMacías et al., 2010). Freezing and frozen storage of HM mozzarella cheese may lead to partial dehydration of the casein micelles and to the consequent modification of the water distribution in the matrix (Graiver et al., 2004; Kuo and Gunasekaran, 2009). It has been previously shown that the formation of larger aggregates of casein is associated with increased opacity of the cheese (Langton and Hermansson, 1992; Pastorino et al., 2002). In this case, the decrease of $\mathrm{L}^{*}$ values can be attributed to changes in the distribution of fat in the matrix, as well as an increase of the degree of oxidation of the cheese lipid phase and nonenzymatic browning resulting from oxidation products and amino acids, as previously reported (Trobetas et al., 2008; Mahajan et

Table 2. External and internal colorimetric coordinates ${ }^{1}$ as a function of frozen storage times

\begin{tabular}{llccc}
\hline Cheese zone & $\begin{array}{l}\text { Frozen storage } \\
(\mathrm{mo})^{2}\end{array}$ & $\mathrm{~L}^{*}$ & $\mathrm{a}^{*}$ & $\mathrm{~b}^{*}$ \\
\hline External part & 0 & $94.1^{\mathrm{a}} \pm 0.3$ & $0.3^{\mathrm{a}} \pm 0.1$ & $13.5^{\mathrm{b}} \pm 0.5$ \\
& 1 & $93.3^{\mathrm{b}} \pm 0.4$ & $0.3^{\mathrm{a}} \pm 0.1$ & $15.0^{\mathrm{a}} \pm 0.5$ \\
& 3 & $93.1^{\mathrm{b}} \pm 0.5$ & $0.4^{\mathrm{a}} \pm 0.1$ & $15.4^{\mathrm{a}} \pm 1.0$ \\
& 4 & $93.4^{\mathrm{b}} \pm 0.3$ & $0.4^{\mathrm{a}} \pm 0.2$ & $15.0^{\mathrm{a}} \pm 0.6$ \\
Inner part & 0 & $92.1^{\mathrm{a}} \pm 0.8$ & $0.3^{\mathrm{a}} \pm 0.1$ & $19.1^{\mathrm{a}} \pm 1.1$ \\
& 1 & $91.4^{\mathrm{b}} \pm 0.6$ & $0.3^{\mathrm{a}} \pm 0.1$ & $19.5^{\mathrm{a}} \pm 0.6$ \\
& 3 & $91.5^{\mathrm{b}} \pm 0.4$ & $0.3^{\mathrm{a}} \pm 0.1$ & $19.1^{\mathrm{a}} \pm 0.8$ \\
& 4 & $91.7^{\mathrm{ab}} \pm 0.5$ & $0.3^{\mathrm{a}} \pm 0.1$ & $19.0^{\mathrm{a}} \pm 0.8$ \\
\hline
\end{tabular}

\footnotetext{
${ }_{\mathrm{a}, \mathrm{b}}$ Mean values within a column with different superscript letters are significantly different $(P<0.05)$.

${ }^{1} \mathrm{~L}^{*}=$ lightness of color, $\mathrm{a}^{*}=$ redness, and $\mathrm{b}^{*}=$ yellowness, according to CIE $\mathrm{L}^{*} \mathrm{a}^{*} \mathrm{~b}^{*}$ color space; reported as means of all refrigerated storage times.

${ }^{2} 0 \mathrm{mo}=$ fresh, nonfrozen cheese.
} 
al., 2015). The higher extent of oxidation of the cheese at longer freezing times was also confirmed by the increase in $\mathrm{b}^{*}$ values that was statistically significant $(P$ $<0.05$ ) in the outer part (Table 2; Supplemental Table S1, https://doi.org/10.3168/jds.2020-18396), which can be related to the formation of secondary oxidation products or to Maillard-type reactions (Kristensen et al., 2001; Cattaneo et al., 2005). On the other hand, a* values did not show significant differences with frozen storage $(P>0.05)$.

\section{Characterization of Protein Profile by SDS and Urea PAGE}

The SDS PAGE protein distributions of $\mathrm{HM}$ mozzarella samples at different frozen and refrigerated storage times are reported in Figure 1. The samples did not show a good separation of the casein, $\beta-\mathrm{CN}$ and $\alpha_{S^{-}} \mathrm{CN}$ (bands located between 29 and $34 \mathrm{kDa}$ ), with the exception of para-k-CN, characterized by a very different molecular weight (MW), of about $13 \mathrm{kDa}$. However, it was possible to clearly distinguish the higher and lower MW fraction, the latter corresponding to casein degradation products.

All mozzarella cheese samples were characterized by a population migrating at higher MW compared with the intact casein. As the samples were run under nonreducing conditions, the small population of high MW bands could be attributed to residual proteins from the milk fat globule membrane, as well as BSA, $\alpha_{S_{2}-}$ CN dimers (Nielsen et al., 2019), whey protein aggregates (Galani and Apenten, 1999), or whey proteinCN complexes linked by disulfide bonds (Havea et al., 2004). These aggregates form during cheese making as a consequence of temperature treatment reached during milk pasteurization and the stretching step after curd formation (Manzo et al., 2008).

Several low MW degradation products were observed from the electrophoretogram. This indicated a mild proteolytic activity in the days immediately after cheese making, as the cheese was kept in the brine in closed bags for $6 \mathrm{~d}$ at $4^{\circ} \mathrm{C}$ before freezing experiments. This proteolysis was minimal as no starter cultures were added during cheesemaking and was probably mainly

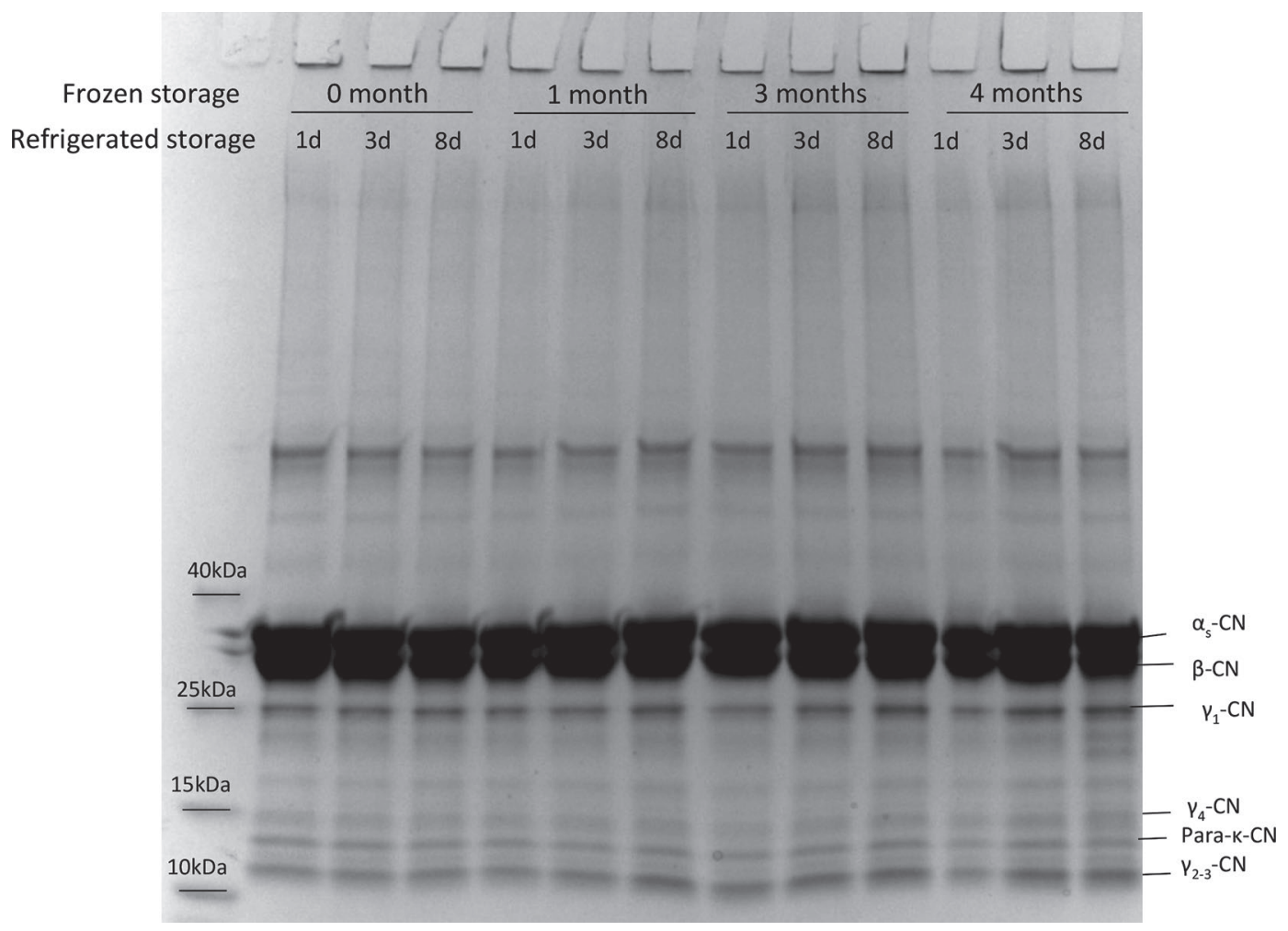

Figure 1. Sodium dodecyl sulfate PAGE of high-moisture mozzarella cheese samples at different times of frozen and refrigerated storage. The major proteins $\left(\beta-\mathrm{CN}, \alpha_{\mathrm{S}} \mathrm{CN}\right.$, para- $\left.\kappa-\mathrm{CN}\right)$ are indicated on the gel; also, $\gamma_{1}-\mathrm{CN}, \gamma_{2}$-CN, $\gamma_{3}$-CN, and $\beta$-CN (f69-209) $\left(\gamma_{4}\right)$ were identified according to literature data. Results are those of one representative batch. 
caused by indigenous enzymes (e.g., plasmin) and enzymes derived from psychrotrophic bacteria (Ismail and Nielsen, 2010; Tribst et al., 2019). However, the contribution of the residual activity of microbial coagulant, which can be inactivated by increasing temperature, cannot completely be neglected as observed later with urea PAGE results.

Results shown in Figure 1 clearly demonstrate that during storage at refrigerated or frozen conditions, it was not possible to note further proteolysis, as the bands corresponding to casein and high MW aggregates did not show a decrease of intensity, and the low MW did not show a significant difference $(P>0.05)$. Among the other low MW fractions, it was possible to identify $\gamma_{1^{-}}, \gamma_{2^{-}}, \gamma_{3^{-}}$, and $\beta-\mathrm{CN}$ (f69-209) $\left(\gamma_{4}\right)$, according to literature data (Somma et al., 2008; Di Luccia et al., 2009; Petrella et al., 2015). Only a slight increase of intensity can be observed at longer frozen storage times for $\gamma_{1^{-}}, \gamma_{2^{-}}$, and $\gamma_{3}$-CN.

To have a better insight of primary proteolysis involving casein in cheese products, Urea PAGE was also performed (Figure 2) as reported in the literature as a better method do identify protein hydrolysis during cheese ripening (Petrella et al., 2015). In this case, the major casein $\left(\beta-\mathrm{CN}, \alpha_{\mathrm{S} 1}-\mathrm{CN}\right.$, and $\left.\alpha_{\mathrm{S}_{2}}-\mathrm{CN}\right)$ are better separated than with SDS PAGE, and it is possible to detect bands corresponding to $\gamma_{1^{-}}, \gamma_{2^{-}}, \gamma_{3^{-}} \mathrm{CN}, \alpha_{\mathrm{S}_{1}} \mathrm{I}$ (f24-199), and casein low MW degradation products, mainly attributable to $\alpha_{\mathrm{S} 1}-\mathrm{CN}$ (Costabel et al., 2007; Sharma Khanal et al., 2019).

Urea PAGE confirmed that $\beta-\mathrm{CN}$ degradation was relatively high at the beginning of refrigerated storage (1 d of refrigerated storage, $\sim 39 \%$ ), in accordance with Lamichhane et al. (2019), and it confirmed an increase in the population of $\gamma_{1^{-}}, \gamma_{2^{-}}, \gamma_{3^{-}} \mathrm{CN}$ at long frozen and refrigerated storage times. This increase in concentration is related to the activity of residual plasmin in the cheese (Costabel et al., 2007). It is important to note that the concentration of $\gamma$-CN did not increase in fresh, nonfrozen cheese during refrigerated storage $(1,3$, or 8 d). It was then concluded that the frozen-stored casein matrix becomes more susceptible to proteolysis after freezing, during the subsequent refrigerated storage period (Bertola et al., 1996). Accordingly, $\alpha_{S 1}$ hydrolysis also followed this trend, and lower MW products were found from 1 mo of frozen storage. Moreover, a slight increase was observed in the intensity of $\alpha_{\mathrm{S} 1}-\mathrm{I}(\mathrm{f} 24-199)$ during the 8 -d refrigerated storage time $(\sim 5 \%$ if related

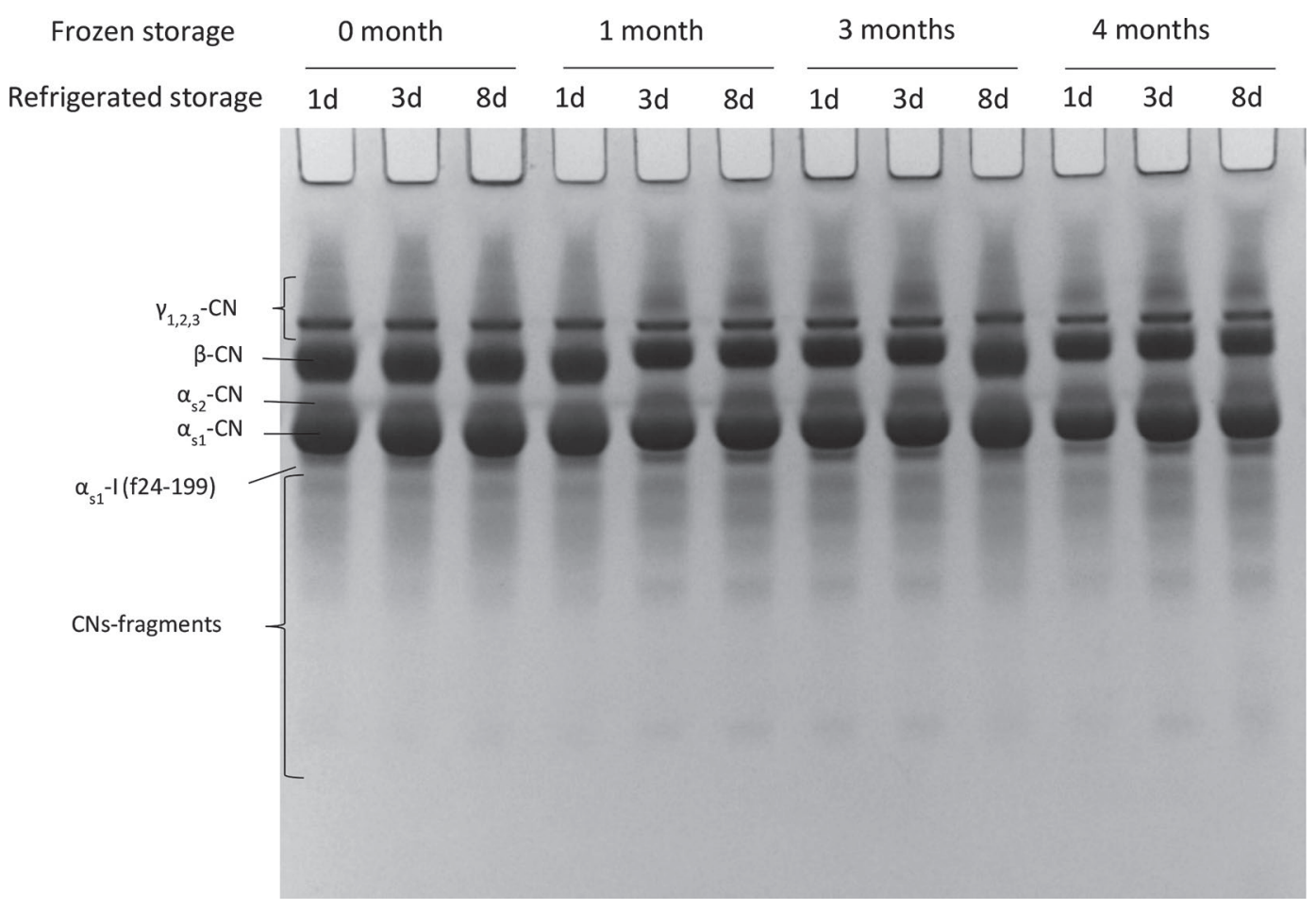

Figure 2. Urea PAGE of high-moisture mozzarella samples at different times of frozen and refrigerated storage. The major proteins $\beta$-CN, $\alpha_{\mathrm{S}_{1}}-\mathrm{CN}, \alpha_{\mathrm{S}_{2}}-\mathrm{CN}, \gamma_{1}-\mathrm{CN}, \gamma_{2}-\mathrm{CN}, \gamma_{3}$ - $\mathrm{CN}, \alpha_{\mathrm{S} 1}-\mathrm{I}$ (f24-199), and casein degradation products are indicated on the gel. Results are representative of one cheese batch. 
to intensity of intact $\alpha_{\mathrm{S} 1}$-CN; Figure 2), which can be caused by the residual activity of the microbial coagulant.

\section{Evaluation of Proteolysis by Reverse-Phase HPLC and Fluorescamine Assay}

Chromatographic analyses separated the major casein fractions para- $\kappa-\mathrm{CN}, \alpha_{\mathrm{S}^{2}} \mathrm{CN}, \alpha_{\mathrm{S}^{-}} \mathrm{CN}$, and $\beta-\mathrm{CN}$, with $\alpha_{S_{1}}-\mathrm{CN}$ and $\beta$-CN that were also separated on the basis of their different genetic variant: $\alpha_{\mathrm{S} 1}-\mathrm{CN}-8 \mathrm{P}$ and $\alpha_{\mathrm{S}_{1}}-\mathrm{CN}-9 \mathrm{P}$, and $\beta-\mathrm{CN} \mathrm{A} 1, \beta-\mathrm{CN} \mathrm{A} 2$, and $\beta-\mathrm{CN} \mathrm{B}$ (Frederiksen et al., 2011; Bijl et al., 2014).

Minor peaks (Figure 3, peak regions identified as 1, 2 , and 3 ), corresponding to degradation products of casein (Jansson et al., 2014; Nielsen et al., 2018; Zhang et al., 2018) were also clearly separated by chromatography. Peak 1 was mainly related to $\alpha_{\mathrm{S1}}-\mathrm{CN}$ degradation products, and peak 3 to $\gamma-\mathrm{CN}$ (Rauh, 2014). These peaks were already present in the fresh, nonfrozen control cheese at $1 \mathrm{~d}$ of refrigerated storage, as discussed above, as a consequence of the mild proteolysis occurring during the initial storage before freezing. In accordance with urea PAGE results, it was possible to observe an increase in the area of degradation at longer storage times.

Statistical analysis (Supplemental Table S2, https: //doi.org/10.3168/jds.2020-18396), demonstrated that there was a significant effect of frozen and refrigerated storage over the relative percentage of the degradation

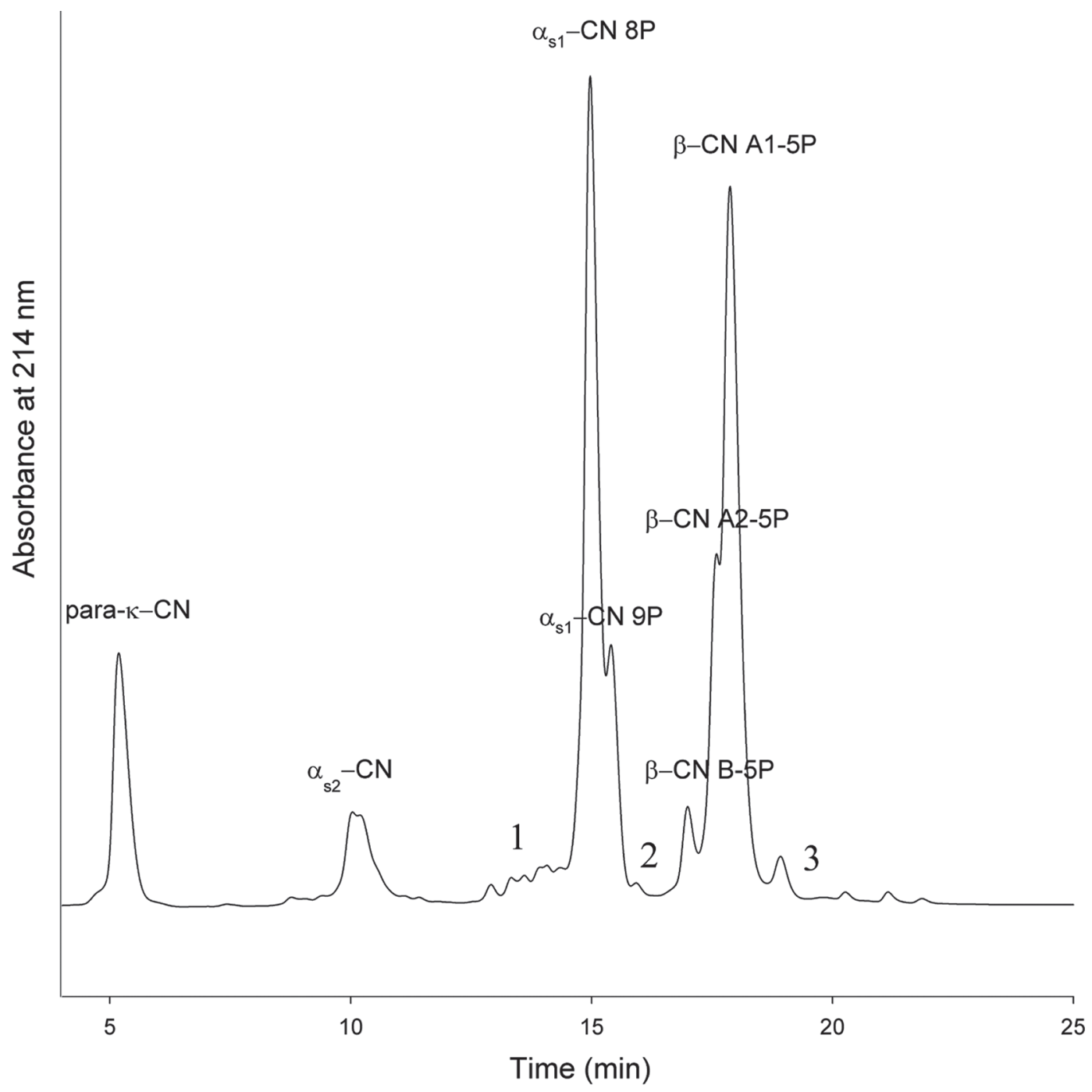

Figure 3. Casein composition as analyzed by reverse-phase HPLC for a representative sample of high-moisture mozzarella cheese (batch 3,3 mo of frozen storage and $8 \mathrm{~d}$ of refrigerated storage) where main genetic variants and isoforms of major milk casein are reported. Peaks labeled as 1,2 , and 3 are degradation products of casein. 
products peaks (peaks 1 and 3 ), and an effect of refrigerated storage over peak $2(P<0.05)$. Furthermore, there was a significant decrease in the amount of $\beta$-CN over refrigerated storage (Table 3 ), but there was no significant difference in the relative concentrations of $\alpha_{\mathrm{S} 1}-\mathrm{CN}$, $\alpha_{\mathrm{S}^{2}} \mathrm{CN}$, and para- $\kappa-\mathrm{CN}(P>0.05)$. It was concluded that the main substrate for proteolytic enzymes was $\beta-\mathrm{CN}$, and that this protein was mainly hydrolyzed into $\gamma-\mathrm{CN}$ by the activity of plasmin (Kelly and McSweeney, 2003), as this endogenous enzyme is not inactivated by milk pasteurization, nor by the cheese making process, including curd stretching. Heat stresses, such those occurring during HM mozzarella cheese making process, can promote the conversion of plasminogen to plasmin, because of the inactivation of the inhibitors of this enzyme (Lucey et al., 2003). Among the 3 peaks of casein degradation, peak 3 showed a statistically significant interaction between frozen and refrigerated storage $(P$ $<0.05)$. As shown in Figure 4, there seemed to be a difference in the proteolysis rate depending on frozen and refrigerated storage times. In particular, longer times of frozen storage determined a higher rate of proteolysis during the subsequent refrigerated storage (Figure 4), also in accordance with observations made with urea PAGE. This difference in the activity of proteases may be caused by the supramolecular changes that may occur during prolonged frozen storage (Alvarenga et al., 2013) that can be related to changes in the hydration status of casein, modifications of the calcium balance, or structural changes promoted by ice crystal growth (Diefes et al., 1993; Kuo and Gunasekaran, 2009; Alinovi and Mucchetti, 2020). The possible resulting conformational change can promote the activity of plasmin and other indigenous enzymes and the accessibility of the enzymes to the substrate (Verdini et al., 2005).
Furthermore, citric mozzarella cheese represent a more favorable substrate for plasmin activity, as it typically has a higher $\mathrm{pH}$ compared with that of mozzarella cheese obtained with fermentation by starter culture (Mucchetti et al., 2017).

The differences in the kinetics of proteolysis with storage and freezing time were also confirmed by the estimation of free amino groups made by the fluorescamine assay (Figure 5). In this case also, there was a significant $(P<0.05)$ effect of frozen storage $(F t)$ refrigerated storage $(R t)$, and frozen storage $\times$ refrigerated storage $(F t \times R t$; Supplemental Table S2, https:/ /doi.org/10.3168/jds.2020-18396).

Despite the significant $(P<0.05)$ increase of proteolysis during frozen storage and refrigerated storage periods measured with HPLC and fluorescamine assay and observed with urea PAGE, the extent of casein degradation estimated was low; for example, the decrease of $\beta-\mathrm{CN}$ measured with reverse-phase HPLC was around $4.5 \%$ for cheese stored frozen for 4 mo then refrigerated for $1 \mathrm{~d}$, and $10 \%$ for cheese stored frozen for 4 mo then refrigerated for $8 \mathrm{~d}$, compared with the control cheese at $1 \mathrm{~d}$ of refrigerated storage. This degradation is much lower than that reported for refrigerated HM mozzarella. Faccia et al. (2019) reported that proteolysis of mozzarella cheese manufactured by direct acidification with lactic acid and stored for $21 \mathrm{~d}$ in refrigerated conditions was approximately $50 \%$ for both $\beta-\mathrm{CN}$ and $\alpha_{S^{-}} \mathrm{CN}$.

\section{Rheological Properties}

The frequency dependence of both $\mathrm{G}^{\prime}$ and $\mathrm{G}^{\prime \prime}$ was well explained by proposed power law models (Equations 1 and $\left.2 ; 0.96<\mathrm{R}^{2}<0.99\right)$. According to the

Table 3. Total protein content of $\beta$-CN and casein degradation products measured with reverse-phase HPLC, and fluorescamine results of fresh and frozen-stored mozzarella cheeses ${ }^{1}$

\begin{tabular}{|c|c|c|c|c|c|c|}
\hline $\begin{array}{l}\text { Frozen storage } \\
(\mathrm{mo})\end{array}$ & $\begin{array}{l}\text { Refrigerated } \\
\text { storage }(d)\end{array}$ & $\beta-\mathrm{CN}(\%)$ & Peak $1(\%)$ & Peak $2(\%)$ & Peak $3(\%)$ & $\begin{array}{l}\text { Fluorescamine } \\
\text { (leucine } \\
\text { equivalents, } \mathrm{m} M \text { ) }\end{array}$ \\
\hline \multirow[t]{2}{*}{0} & 1 & $40.3^{\mathrm{a}} \pm 0.5$ & $3.7^{\mathrm{d}} \pm 0.2$ & $0.31^{\mathrm{b}} \pm 0.06$ & $1.35^{\mathrm{e}} \pm 0.17$ & $0.23^{\mathrm{c}} \pm 0.08$ \\
\hline & 8 & $37.9^{\text {edf }} \pm 0.5$ & $4.4^{\mathrm{bcd}} \pm 0.1$ & $0.39^{\mathrm{ab}} \pm 0.02$ & $1.70^{\mathrm{bcd}} \pm 0.08$ & $0.31^{\mathrm{cb}} \pm 0.06$ \\
\hline \multirow[t]{2}{*}{1} & 1 & $39.8^{\mathrm{ab}} \pm 1.3$ & $4.0^{\mathrm{cd}} \pm 0.2$ & $0.38^{\mathrm{ab}} \pm 0.01$ & $1.55^{\text {de }} \pm 0.03$ & $0.23^{\mathrm{c}} \pm 0.05$ \\
\hline & 3 & $38.8^{\text {bcd }} \pm 1.2$ & $4.3^{\text {cd }} \pm 0.3$ & $0.42^{\mathrm{ab}} \pm 0.02$ & $1.68^{\mathrm{bcd}} \pm 0.08$ & $0.25^{\mathrm{c}} \pm 0.09$ \\
\hline \multirow{2}{*}{3} & 3 & $38.5^{\text {bcd }} \pm 1.3$ & $4.6^{\mathrm{abcd}} \pm 0.7$ & $0.55^{\mathrm{ab}} \pm 0.21$ & $1.91^{\mathrm{bc}} \pm 0.32$ & $0.29^{\mathrm{cb}} \pm 0.06$ \\
\hline & 8 & $36.9^{\mathrm{gf}} \pm 0.8$ & $5.3^{\mathrm{ab}} \pm 1.0$ & $0.73^{\mathrm{a}} \pm 0.43$ & $2.65^{\mathrm{a}} \pm 0.33$ & $0.78^{\mathrm{a}} \pm 0.25$ \\
\hline \multirow[t]{3}{*}{4} & 1 & $38.9^{\text {bcd }} \pm 0.7$ & $4.6^{\mathrm{bcd}} \pm 0.2$ & $0.42^{\mathrm{ab}} \pm 0.02$ & $1.79^{\mathrm{bcd}} \pm 0.25$ & $0.25^{\mathrm{c}} \pm 0.03$ \\
\hline & 3 & $38.5^{\mathrm{bcd}} \pm 1.2$ & $4.7^{\mathrm{abc}} \pm 0.3$ & $0.48^{\mathrm{ab}} \pm 0.02$ & $1.95^{\mathrm{b}} \pm 0.23$ & $0.43^{\mathrm{cb}} \pm 0.05$ \\
\hline & 8 & $36.3^{\mathrm{g}} \pm 1.7$ & $5.5^{\mathrm{a}} \pm 0.5$ & $0.60^{\mathrm{a}} \pm 0.15$ & $2.51^{\mathrm{a}} \pm 0.18$ & $0.79^{\mathrm{a}} \pm 0.25$ \\
\hline
\end{tabular}

\footnotetext{
${ }^{\mathrm{a}-\mathrm{g}}$ Mean values within a column with different superscript letters are significantly different $(P<0.05)$.

${ }^{1} 0 \mathrm{mo}=$ fresh, nonfrozen cheese; refrigerated storage indicates time refrigerated after frozen samples were thawed; peaks 1,2 , and 3 represent the relative percentage of casein degradation products observed in the samples as indicated in Figure 3.
} 
power law models, the frequency dependence of dynamic rheological parameters can be estimated from $\mathrm{n}^{\prime}, \mathrm{n}^{\prime \prime}$ and $\mathrm{n}^{*}$ values reported in Equations 1, 2 and 3. Frequency curves of dynamic moduli $\left(\mathrm{G}^{\prime}, \mathrm{G}^{\prime \prime}\right)$ showed the predominance of the elastic behavior in mozzarella cheeses; $\mathrm{G}^{\prime}$ was higher than $\mathrm{G}^{\prime \prime}$ in the whole frequency range, as the moduli increased with a relatively similar rate ( $n^{\prime}$ and $n^{\prime \prime}$ values, Table 4 ).

This is in agreement with previous work, where HM mozzarella cheese was shown to exhibit a solid-like behavior in the whole frequency range analyzed, as $\mathrm{G}^{\prime}$ was higher than $\mathrm{G}^{\prime \prime}$ with no presence of crossover points in the curves (Alinovi and Mucchetti, 2020). Unlike LM mozzarella cheese analyzed by other authors (Muliawan and Hatzikiriakos, 2007; Ribero et al., 2007), in this work, HM mozzarella cheese showed, as expected, a lower elastic response because of the higher moisture content, the larger pore sizes, and the related viscous dissipation.

As it is reported in Table 4, rheological moduli and complex viscosity at $1 \mathrm{~Hz}$ did not show significant effects of frozen storage and refrigerated storage, and of their interaction $(P>0.05)$. This nonsignificant variation of rheological moduli could also be caused by the simultaneous presence of mild proteolytic phenomena observed in this paper, and the occurrence of casein dehydration during freezing and frozen storage; this second phenomenon has been widely reported in the case of pasta-filata and nonpasta-filata cheese freezing (Diefes et al., 1993; Kuo and Gunasekaran 2009; Ribero et al., 2009; Alberini et al., 2015; Alinovi and Mucchetti, 2020), and it can cause the formation of a more rigid and crosslinked protein structure that is less plasticized by the presence of interstitial water or by the fat phase. This phenomenon, which was also observed in HM mozzarella cheeses used in this study by performing low field NMR relaxometry (results not shown), can compensate the possible reduction of the gel elastic behavior consequent to proteolysis.

The only factor in the statistical models that showed significance only for $\mathrm{G}^{\prime}$ and $\mathrm{G}^{\prime \prime}$ at $1 \mathrm{~Hz}$ was the blocking factor (batch); despite the standardized cheese making procedure, differences in terms of rheological behavior of obtained cheeses were still appreciable.

The frequency dependence of dynamic rheological parameters, can be useful to describe the type of bonding between structural elements present in the matrix (Sharma et al., 2016). The frequency dependence of rheological parameters was not influenced by the different process factors as the $\mathrm{n}^{\prime}, \mathrm{n}^{\prime \prime}, \mathrm{n}^{*}$ terms were not different among treatments $(P>0.05)$. In general, samples were characterized by a relatively low frequen-

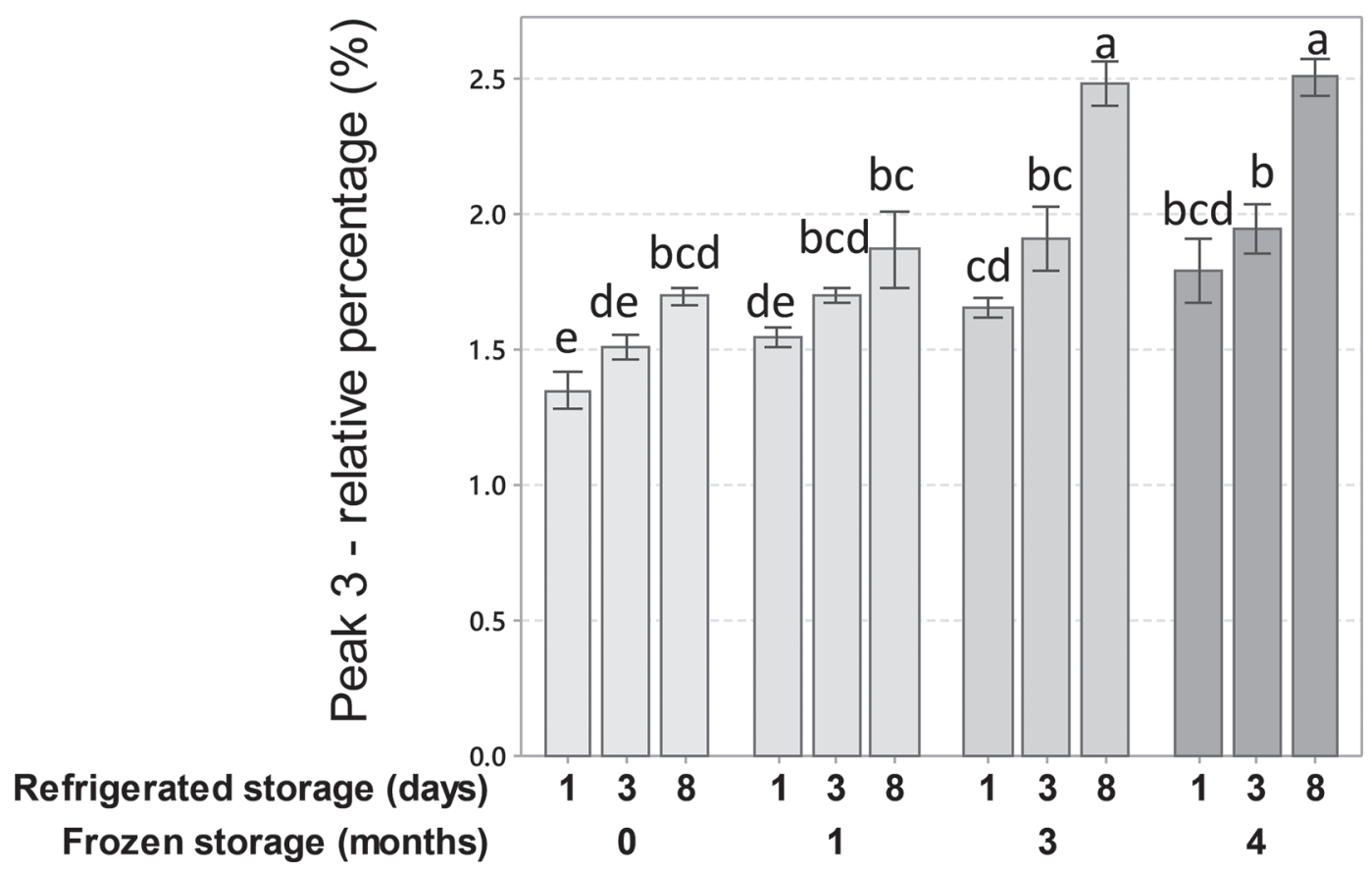

Figure 4. Extent of casein degradation as a function of storage conditions, measured as peak area (see Figure 3, peak 3) for mozzarella cheeses stored in frozen and refrigerated conditions for different times; 0 mo of frozen storage represents the fresh, nonfrozen cheese samples at 1,3 , and $8 \mathrm{~d}$ of refrigerated storage. Results are expressed as mean \pm SE. Different letters $(\mathrm{a}-\mathrm{e})$ indicate means that are statistically different $(P<0.05)$ 


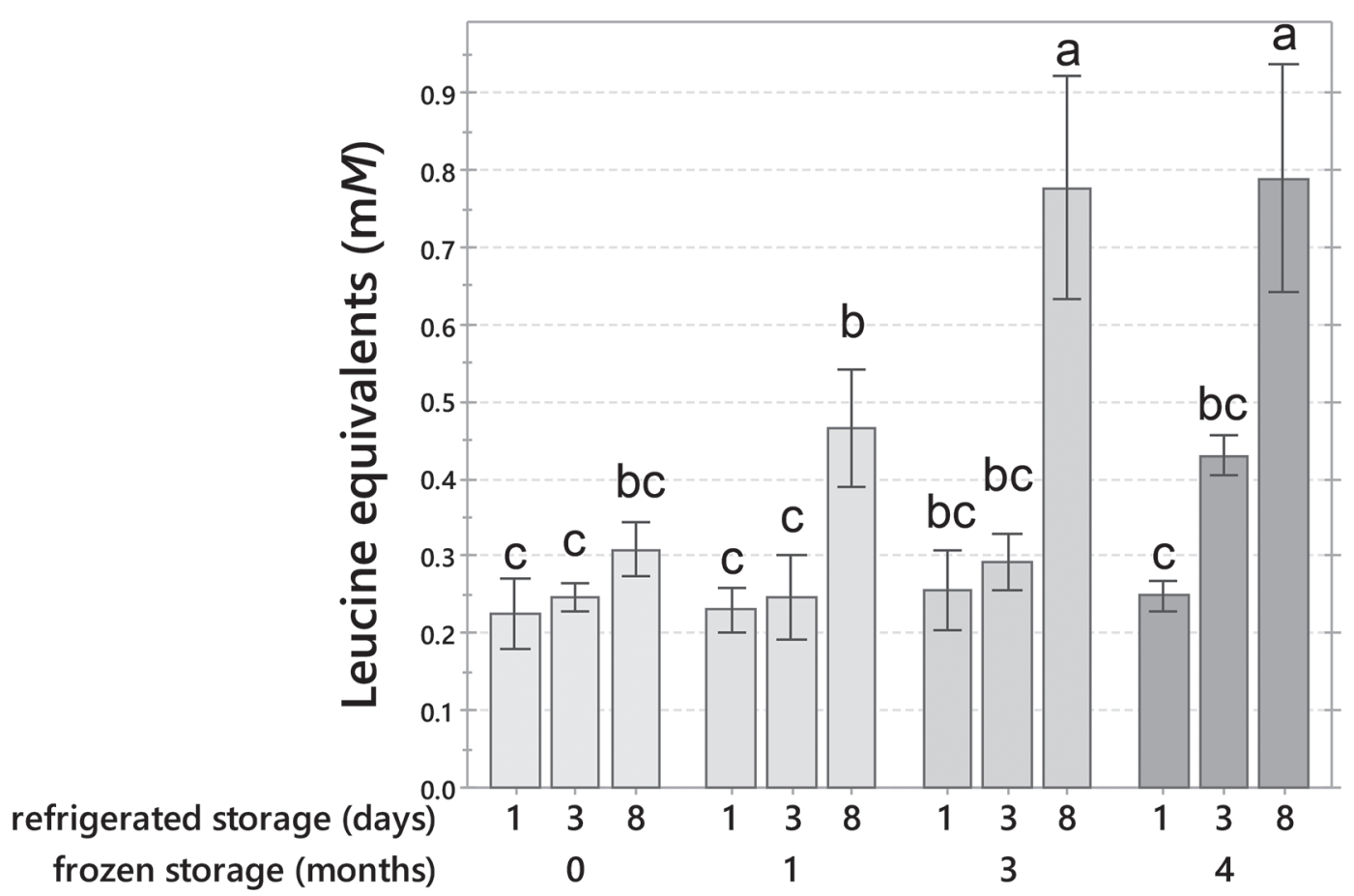

Figure 5. Free amino terminal estimation by fluorescamine assay as leucine equivalents $(\mathrm{m} M)$ in high-moisture mozzarella cheeses stored in frozen and refrigerated conditions for different times; 0 mo of frozen storage represents the fresh, nonfrozen cheese samples stored for 1 , 3 , and $8 \mathrm{~d}$ of refrigerated storage. Results are expressed as mean \pm SE. Different letters indicate means that are statistically different $(P<0.05)$.

cy dependence $\left(0.166<\mathrm{n}^{\prime}<0.177,0.162<\mathrm{n}^{\prime \prime}<0.170\right.$, $\left.0.166<\mathrm{n}^{*}<0.172\right)$, indicating the presence of strong and cross-linked gels with permanent covalent bonds (Banville et al., 2014; Sharma et al., 2016).

Considering these results, the freezing process and the frozen storage and refrigerated storage applied did not significantly change $(P>0.05)$ the rheological properties of the cheese matrix.

\section{Sensory Properties}

From a sensory point of view, cheeses showed differences in the intensity of bitter and oxidized tastes, whereas the other parameters were not affected by both frozen storage and refrigerated storage (Supplemental Table S3, https://doi.org/10.3168/jds.2020-18396).

Frozen storage also promoted the formation of oxidized and bitter tastes; the first one was found to be significant $(P<0.05)$ already from the first month of frozen storage, whereas the second sensory attribute was significantly higher $(P<0.05)$ from the third month (Figure 6C, D). The increase in bitterness of the cheese was related to the increase in proteolysis during the frozen storage period $(\mathrm{r}>0.500$ with degradation products measured with HPLC); it is well known that the depletion of peptides (in particular hydrophobic fragments) from casein can promote the formation of bitter tastes (Alinovi et al., 2018a). In particular, the residual activ-

Table 4. Rheological parameters measured at $25^{\circ} \mathrm{C}$ and derived from frequency sweeps fitted using power law regression equations ${ }^{1}\left(\mathrm{G}^{\prime}, \mathrm{G}^{\prime \prime}, \mathrm{G}^{*}\right.$ at $\left.1 \mathrm{~Hz} ; \mathrm{n}^{\prime}, \mathrm{n}^{\prime \prime}, \mathrm{n}^{*}\right)$ of fresh and frozen-stored high-moisture mozzarella cheeses

\begin{tabular}{|c|c|c|c|c|c|c|}
\hline $\begin{array}{l}\text { Frozen storage } \\
(\mathrm{mo})^{2}\end{array}$ & $\mathrm{G}^{\prime}(\mathrm{kPa} \cdot \mathrm{s})$ & $\mathrm{G}^{\prime \prime}(\mathrm{kPa} \cdot \mathrm{s})$ & $\eta^{*}(\mathrm{kPa} \cdot \mathrm{s})$ & $\mathrm{n}^{\prime}$ & $\mathrm{n}^{\prime \prime}$ & $\mathrm{n}^{*}$ \\
\hline 0 & $15.2 \pm 6.6$ & $4.8 \pm 2.1$ & $2.6 \pm 1.2$ & $0.166 \pm 0.009$ & $0.162 \pm 0.012$ & $0.166 \pm 0.009$ \\
\hline 1 & $13.8 \pm 5.4$ & $4.4 \pm 1.7$ & $2.3 \pm 0.9$ & $0.172 \pm 0.008$ & $0.164 \pm 0.007$ & $0.172 \pm 0.008$ \\
\hline 4 & $13.5 \pm 4.1$ & $4.3 \pm 1.3$ & $2.2 \pm 0.7$ & $0.177 \pm 0.016$ & $0.169 \pm 0.014$ & $0.176 \pm 0.016$ \\
\hline
\end{tabular}

${ }^{1} \mathrm{G}^{\prime}=$ storage modulus; $\mathrm{G}^{\prime \prime}=$ loss modulus; $\eta^{*}=$ complex viscosity; $\mathrm{n}^{\prime}=$ frequency dependence index of $\mathrm{G}^{\prime} ; \mathrm{n}^{\prime \prime}=$ frequency dependence index of $\mathrm{G}^{\prime \prime}$; and $\mathrm{n}^{*}=$ frequency dependence index of $\eta^{*}$.

${ }^{2} 0 \mathrm{mo}=$ fresh, nonfrozen cheese; reported as means of all refrigerated storage times. 
(A)

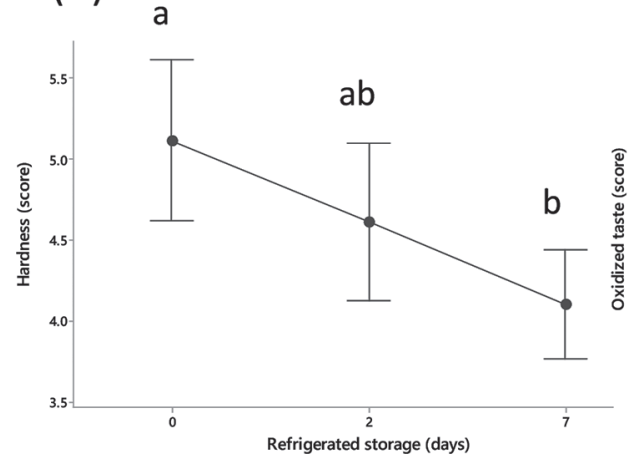

(B)

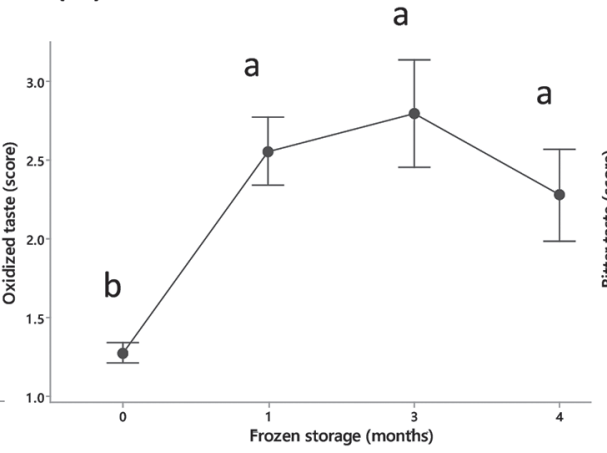

(C)

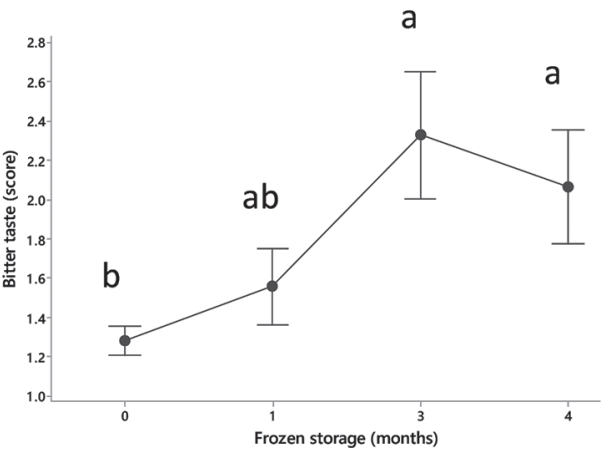

Figure 6. Variation of sensory hardness (A) as a function of refrigerated storage (days) and reported as means of all frozen storage times. Variation of perceived oxidized (B) and bitter tastes (C) as a function of frozen storage (months) and reported as means of all refrigerated storage times. Values are expressed as score points (minimum score 0, maximum score 9 ) evaluated by a trained panel group $(\mathrm{n}=5)$. Results are expressed as mean $\pm \mathrm{SE}$. Different letters indicate means that are statistically different $(P<0.05)$.

ity of proteases, such as plasmin, coagulating enzymes, or microbial proteases can liberate potentially bitter peptides from $\alpha_{\mathrm{S}^{-}} \mathrm{CN}$ (e.g., f23-34, f91-100, f100-105), found in HM mozzarella cheese (Faccia et al., 2014), and from $\beta$-CN (e.g., f193-209, f106-113, f190-209) or $\alpha_{\mathrm{S} 2}$-CN (e.g., f171-181, f182-207, f189-207) (Fox and McSweeney, 1997; Sousa et al., 2001; Rauh et al., 2014).

In the same way, the appearance of oxidized flavor in HM mozzarella cheese can be mainly caused by the residual activity of endogenous and microbial lipases and the presence of oxygen, that can penetrate through the packaging material. It has been reported that frozen storage induces a significant $(P<0.05)$ deactivation of lipase enzymes in sheep's milk, but without completely deactivating it (Needs, 1992). Also, ice crystal growth during frozen storage can contribute to the higher extent of oxidative phenomena, as it can cause the rupture of fat globule membranes, release of acylglycerols in the matrix that can be subsequently hydrolyzed in fatty acids and become more propense to oxidation (Voutsinas et al., 1995b; Tribst et al., 2020). The presence of oxidative phenomena in this study was also indirectly confirmed by changes in the color of the cheese, that was significantly $(P<0.05)$ correlated $(\mathrm{r}=-0.457$ and $\mathrm{r}=0.444$ with $\mathrm{L}^{*}$ ext and $\mathrm{b}^{*}$ ext, respectively), as previously reported. On the contrary, as a consequence of the frozen storage period without illumination, the extent of photo-induced oxidation would be low.

Moreover, concerning the refrigerated storage period considered, it was possible to highlight a decrease of sensory hardness, that was significant after $7 \mathrm{~d}$ of refrigerated storage $(P<0.05$; Figure $6 \mathrm{~B})$, and that can be related to casein hydrolysis; in particular, the of $\alpha_{\mathrm{S} 1}-\mathrm{CN}$ f24-199 is recognized to be one of the main contributors to cheese softening (Alinovi et al., 2018a), and it showed a slight increase of its concentration dur- ing the refrigerated storage, as previously reported in urea PAGE results.

\section{Overall Evaluation of Quality Attributes with Freezing, Using PCA}

The totality of measured parameters was included into PCA model to have an overall overview of samples characteristics as a function of the applied storage treatments (Figure 7); 3 principal components (PC) were generated and explained $58.5 \%$ of variance of the data set. The low variance explained by the multivariate model can be due to variability encountered in relation with the batch of cheese, as already observed in the case of univariate analyses, and because the process evaluated variables (frozen storage and refrigerated storage) did not show a strong influence over some measured parameters.

In accordance with the batch-to-batch variation encountered, by using a multivariate approach, it was not possible to clearly classify the samples on the basis of frozen or refrigerated storage (Figure 7A, B). However, a slight separation between fresh and frozen-stored cheeses was still present (Figure 7A); the fresh cheeses were all positioned in the lower part of the graph (negative loadings on the PC 2), while frozen-stored cheeses that were positioned in the upper part (positive loadings on PC 2), and could not be distinguished further by frozen storage time. Moreover, as it is possible to observe in Figure 7B, refrigerated storage did not cluster the cheeses in relation to the measured parameters.

The partial classification of fresh and frozen-stored cheeses was principally due to PC 2 (Figure 7A). This $\mathrm{PC}$, that explained $21.1 \%$ of variance, was mainly represented by positive loadings of proteolysis degradation products measured by reverse-phase HPLC and fluor- 

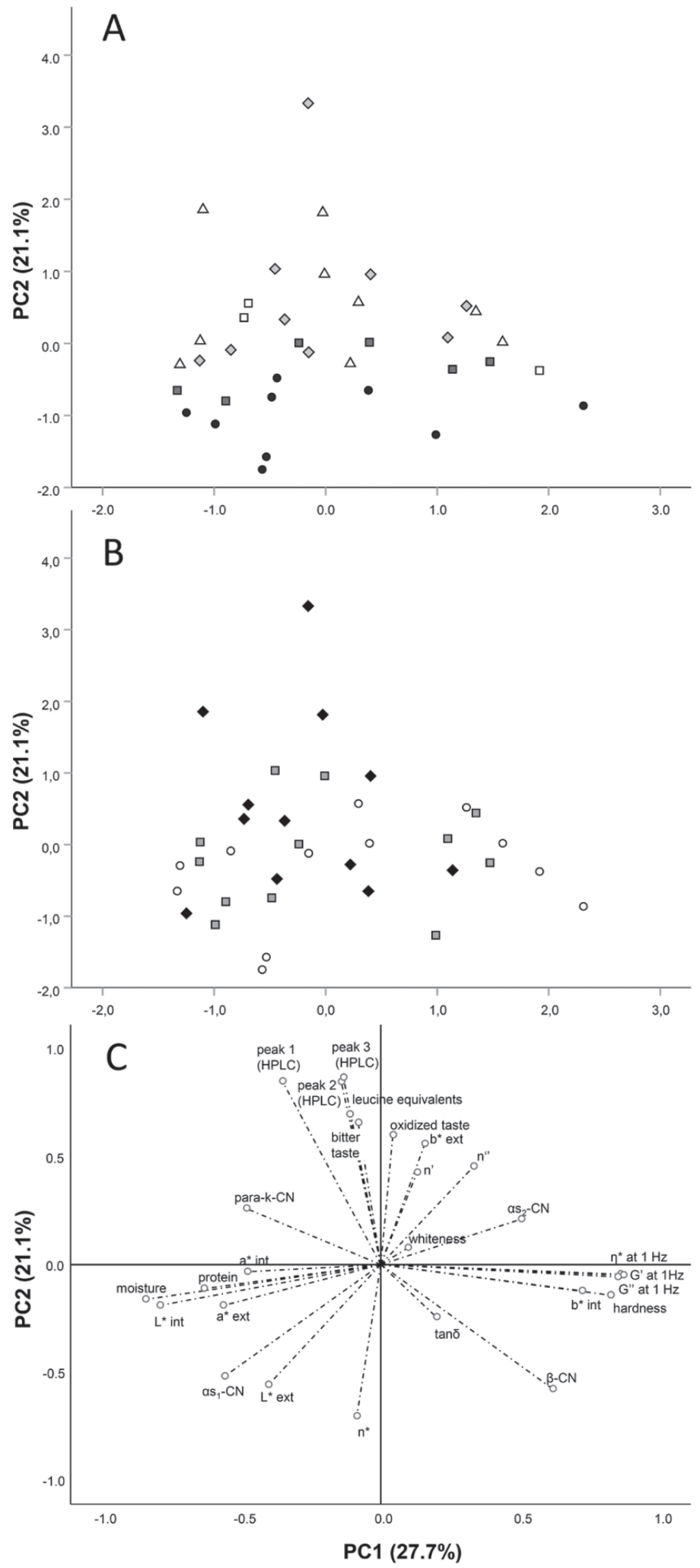

Figure 7. Principal component analysis score (A, B) and loading plots (C). Principal components (PC) were calculated using chemical, physical, rheological, and sensory parameters evaluated in this study. Samples were labeled according to (A) the frozen storage period (circle $=$ $0 \mathrm{mo}$, square $=1 \mathrm{mo}$, diamond $=3 \mathrm{mo}$, triangle $=4 \mathrm{mo})$ and $(\mathrm{B})$ the refrigerated storage period $($ circle $=1 \mathrm{~d}$, square $=3 \mathrm{~d}$, diamond $=8 \mathrm{~d}$; $\mathrm{G}^{\prime}=$ storage modulus; $\mathrm{G}^{\prime \prime}=$ loss modulus; $\eta^{*}=$ complex viscosity; $\mathrm{n}^{\prime}=$ frequency dependence index of $\mathrm{G}^{\prime} ; \mathrm{n}^{\prime \prime}=$ frequency dependence index of $\mathrm{G}^{\prime \prime} ; \mathrm{n}^{*}=$ frequency dependence index of $\left.\eta^{*}\right)$. 
escamine assay, oxidized, bitter tastes and yellowness in the outer part of the cheese ( $b^{*}$ ext); on the contrary, negative-loaded variables were lightness in the external part of the cheese ( $\mathrm{L}^{*}$ ext), complex viscosity behavior index $\left(\mathrm{n}^{*}\right)$, and intact $\alpha_{\mathrm{S}^{-}}$and $\beta$-CNs (Figure $7 \mathrm{C}$ ).

Despite not showing statistical differences as a function of frozen and refrigerated storage, moisture content was inversely correlated with sensory hardness and $\mathrm{G}^{\prime}$ at $1 \mathrm{~Hz}(\mathrm{r}=-0.617,-0.740$, respectively); accordingly, $\mathrm{G}^{\prime}$ at $1 \mathrm{~Hz}$ and sensory hardness were significantly $(P$ $<0.05)$ positively correlated $(\mathrm{r}=0.638)$. By comparing the loading and score plots, fresh cheeses were mainly differentiated from the frozen-thawed cheeses for their lower proteolysis, less oxidized and bitter sensory perception, and different color.

\section{CONCLUSIONS}

Frozen HM citric mozzarella cheeses stored at $-18^{\circ} \mathrm{C}$ for a period of 1 to 4 mo showed higher proteolysis with storage time and different sensory properties than fresh mozzarella cheeses. It was clearly demonstrated that the residual activity of enzymes during frozen storage is responsible for the occurrence of oxidized and bitter sensory attributes. Moreover, an enhanced rate of proteolysis after thawing, primarily caused by plasmin and residual coagulating enzymes, was probably caused by an enhanced access of enzyme to casein due to their structural change during freezing and storage. These are critical points that must be considered when storing HM mozzarella cheese in frozen state, as they will considerably reduce the refrigerated shelf life after thawing and the product's sensory quality. These results can be useful to understand the critical factors affecting HM mozzarella cheese frozen storage and to find ways to limit modifications of the matrix affecting the quality. Further studies should focus on how cheese making practices may influence the characteristics and storability of frozen HM mozzarella cheese.

\section{ACKNOWLEDGMENTS}

The authors thank Fabrizio Salvadorini, Roberto Pastorelli (Nuova Castelli S.p.a., Reggio Emilia, Italy), and Luana Paterni (Alival S.p.a., Ponte Buggianese, Pistoia, Italy) for their valuable contribution in the development of the work, and Caterina Sciunzi (University of Parma, Parma, Italy) for her valuable help in the execution of the experimental trials during her graduate studies. The authors also thank MIUR (Italian Ministry of Education, University and Research) and iFOOD center of Aarhus University, which partly funded this work. The authors declare no conflicts of interest.

\section{REFERENCES}

Alberini, I. C., M. E. Miccolo, and A. C. Rubiolo. 2015. Textural and chemical changes during ripening of Port Salut Argentino light cheese with milk protein concentrate after long frozen storage period. J. Food Process. Preserv. 39:1983-1991. https://doi.org/10 $.1111 /$ jfpp.12438.

Alinovi, M., M. Cordioli, S. Francolino, F. Locci, R. Ghiglietti, L. Monti, F. Tidona, G. Mucchetti, and G. Giraffa. 2018a. Effect of fermentation-produced camel chymosin on quality of Crescenza cheese. Int. Dairy J. 84:72-78. https://doi.org/10.1016/j.idairyj .2018.04.001.

Alinovi, M., and G. Mucchetti. 2020. Effect of freezing and thawing processes on high-moisture mozzarella cheese rheological and physical properties. LWT Food Sci. Technol. 124:109137. https:// doi.org/10.1016/j.lwt.2020.109137.

Alinovi, M., M. Rinaldi, and G. Mucchetti. 2018b. Spatiotemporal characterization of texture of Crescenza cheese, a soft fresh Italian cheese. J. Food Qual. 2018:5062124. https://doi.org/10.1155/ $2018 / 5062124$.

Alvarenga, N., J. Canada, and I. Sousa. 2011. Effect of freezing on the rheological, chemical and colour properties of Serpa cheese. J. Dairy Res. 78:80-87. https://doi.org/10.1017/S0022029910000841.

Alvarenga, N. B., S. P. Ferro, A. S. Almodôvar, J. Canada, and I. Sousa. 2013. Shelf-life extension of cheese: Frozen storage. Pages 87-102 in Handbook of Cheese in Health: Production, Nutrition and Medical Sciences. Vol. 6. V. R. Preedy, R. R. Watson, and V. B. Patel, ed. Wageningen Academic Publishers, Wageningen, the Netherlands.

Andrews, A. T. 1983. Proteinases in normal bovine milk and their action on caseins. J. Dairy Res. 50:45-55. https://doi.org/10.1017/ S0022029900032519.

AOAC. 1990. Official Methods of Analysis of the AOAC. Vol. 2. 15th ed. Association of Official Analytical Chemists, Gaithersburg, MD.

Assolatte. 2018. Industria Lattiero Casearia Italiana. Rapporto 2017. Accessed Feb 18, 2020. http://www.assolatte.it/it/home/news detail/assemblea/1500385748867.

Banville, V., P. Morin, Y. Pouliot, and M. Britten. 2014. Shreddability of pizza mozzarella cheese predicted using physicochemical properties. J. Dairy Sci. 97:4097-4110. https://doi.org/10.3168/jds.2014 -8040 .

Bertola, N. C., A. N. Califano, A. E. Bevilacqua, and N. E. Zaritzky. 1996. Textural changes and proteolysis of low-moisture mozzarella cheese frozen under various conditions. LWT Food Sci. Technol. 29:470-474. https://doi.org/10.1006/fstl.1996.0072.

Bijl, E., H. van Valenberg, S. Sikkes, S. Jumelet, G. Sala, K. Olieman, T. van Hooijdonk, and T. Huppertz. 2014. Chymosin-induced hydrolysis of caseins: Influence of degree of phosphorylation of alpha-s1-casein and genetic variants of beta-casein. Int. Dairy J. 39:215-221. https://doi.org/10.1016/j.idairyj.2014.07.005.

Blakesley, R. W., and J. A. Boezi. 1977. A new staining technique for proteins gels using Coomassie brilliant blue G250. Anal. Biochem. 82:580-582. https://doi.org/10.1016/0003-2697(77)90197-X.

Cattaneo, T. M. P., C. Giardina, N. Sinelli, M. Riva, and R. Giangiacomo. 2005. Application of FT-NIR and FT-IR spectroscopy to study the shelf-life of Crescenza cheese. Int. Dairy J. 15:693-700. https://doi.org/10.1016/j.idairyj.2004.07.026.

CLAL. 2020. Italy, Export Mozzarella. Accessed Feb. 18, 2020. https: //www.clal.it/en/.

Conte, A., J. Laverse, C. Costa, V. Lampignano, M. A. Previtali, and M. A. Del Nobile. 2017. Conventional or blast freezing prior to frozen storage to preserve properties of Fiordilatte cheese. J. Food Process. Preserv. 41:e13235. https://doi.org/10.1111/jfpp.13235.

Costabel, L., M. S. Pauletti, and E. Hynes. 2007. Proteolysis in mozzarella cheeses manufactured by different industrial processes. J. Dairy Sci. 90:2103-2112. https://doi.org/10.3168/jds.2006-795. 
Dalla Riva, A., J. Burek, D. Kim, G. Thoma, M. Cassandro, and M. De Marchi. 2017. Environmental life cycle assessment of Italian mozzarella cheese: Hotspots and improvement opportunities. J. Dairy Sci. 100:7933-7952. https://doi.org/10.3168/jds.2016-12396.

Dalsgaard, T. K., J. H. Nielsen, and L. B. Larsen. 2007. Proteolysis of milk proteins lactosylated in model systems. Mol. Nutr. Food Res. 51:404-414. https://doi.org/10.1002/mnfr.200600112.

Di Luccia, A., G. Picariello, A. Trani, G. Alviti, P. Loizzo, M. Faccia, and F. Addeo. 2009. Occurrence of $\beta$-casein fragments in coldstored and curdled river buffalo (Bubalus bubalis L.) milk. J. Dairy Sci. 92:1319-1329. https://doi.org/10.3168/jds.2008-1220.

Diefes, H. A., S. S. H. Rizvi, and J. A. Bartsch. 1993. Rheological behavior of frozen and thawed low-moisture, part-skim mozzarella cheese. J. Food Sci. 58:764-769. https://doi.org/10.1111/j.1365 -2621.1993.tb09354.x.

Faccia, M., G. Gambacorta, G. Natrella, and F. Caponio. 2019. Shelf life extension of Italian mozzarella by use of calcium lactate buffered brine. Food Control 100:287-291. https://doi.org/10.1016/j .foodcont.2019.02.002.

Faccia, M., A. Trani, P. Loizzo, R. Gagliardi, B. La Gatta, and A. Di Luccia. 2014. Detection of $\alpha_{S 1}$ I casein in mozzarella Fiordilatte: A possible tool to reveal the use of stored curd in cheesemaking. Food Control 42:101-108. https://doi.org/10.1016/j.foodcont.2014 .01 .044 .

Fontana, A. J. 2007. Measurement of water activity, moisture sorption isotherms, and moisture content of foods. Pages 155-171 in Water Activity in Foods: Fundamentals and Applications. G. V. Barbosa-Cánovas, A. J. Fontana, S. J. Schmidt, and T. P. Labuz, ed. Blackwell Publishing Ltd., Oxford, UK.

Fox, P. F., and P. L. H. McSweeney. 1997. Rennets: Their role in milk coagulation and cheese ripening. Pages 1-49 in Microbiology and Biochemistry of Cheese and Fermented Milk. B. A. Law, ed. Springer, Boston, MA.

Francolino, S., F. Locci, R. Ghiglietti, R. Iezzi, and G. Mucchetti. 2010. Use of milk protein concentrate to standardize milk composition in Italian citric mozzarella cheese making. LWT Food Sci. Technol. 43:310-314. https://doi.org/10.1016/j.lwt.2009.08.007.

Frederiksen, P. D., K. K. Andersen, M. Hammershøj, H. D. Poulsen, J. Sørensen, M. Bakman, K. B. Qvist, and L. B. Larsen. 2011. Composition and effect of blending of noncoagulating, poorly coagulating, and well-coagulating bovine milk from individual Danish Holstein cows. J. Dairy Sci. 94:4787-4799. https://doi.org/10 $.3168 /$ jds.2011-4343.

Galani, D., and R. K. O. Apenten. 1999. Heat-induced denaturation and aggregation of $\beta$-Lactoglobulin: Kinetics of formation of hydrophobic and disulphide-linked aggregates. Int. J. Food Sci. Technol. 34:467-476. https://doi.org/10.1046/j.1365-2621.1999.00314.x.

Graiver, N. G., N. E. Zaritzky, and A. N. Califano. 2004. Viscoelastic behavior of refrigerated and frozen low-moisture mozzarella cheese. J. Food Sci. 69:FEP123-128. https://doi.org/10.1111/j.1365-2621 .2004.tb13364.x.

Havea, P., A. J. Carr, and L. K. Creamer. 2004. The roles of disulphide and non-covalent bonding in the functional properties of heat-induced whey protein gels. J. Dairy Res. 71:330-339. https:/ /doi.org/10.1017/S002202990400024X.

Ismail, B., and S. S. Nielsen. 2010. Invited review: Plasmin protease in milk: Current knowledge and relevance to dairy industry. J. Dairy Sci. 93:4999-5009. https://doi.org/10.3168/jds.2010-3122.

Jansson, T., H. B. Jensen, U. K. Sundekilde, M. R. Clausen, N. Eggers, L. B. Larsen, C. Ray, H. J. Andersen, and H. C. Bertram. 2014. Chemical and proteolysis-derived changes during long-term storage of lactose-hydrolyzed ultrahigh-temperature (UHT) milk. J. Agric. Food Chem. 62:11270-11278. https://doi.org/10.1021/ jf504104q.

Jensen, H. B., N. A. Poulsen, K. K. Andersen, M. Hammershøj, H. D. Poulsen, and L. B. Larsen. 2012. Distinct composition of bovine milk from Jersey and Holstein-Friesian cows with good, poor, or noncoagulation properties as reflected in protein genetic variants and isoforms. J. Dairy Sci. 95:6905-6917. https://doi.org/10.3168/ jds.2012-5675.
Kelly, A. L., and P. L. H. McSweeney. 2003. Indigenous proteinases in milk. Pages 495-521 in Advanced Dairy Chemistry. Vol. 1: Proteins. P. L. McSweeney and P. F. Fox, ed. Springer, Boston, MA.

Kristensen, D., E. Hansen, A. Arndal, R. A. Trinderup, and L. H. Skibsted. 2001. Influence of light and temperature on the colour and oxidative stability of processed cheese. Int. Dairy J. 11:837843. https://doi.org/10.1016/S0958-6946(01)00105-4.

Kuo, M.-I., and S. Gunasekaran. 2009. Effect of freezing and frozen storage on microstructure of mozzarella and pizza cheeses. Lebenson. Wiss. Technol. 42:9-16. https://doi.org/10.1016/j.lwt.2008 .07 .003 .

Laemmli, U. K. 1970. Cleavage of structural proteins during the assembly of the head of bacteriophage T4. Nature 227:680-685. https://doi.org/10.1038/227680a0.

Lamichhane, P., P. Sharma, D. Kennedy, A. L. Kelly, and J. J. Sheehan. 2019. Microstructure and fracture properties of semi-hard cheese: Differentiating the effects of primary proteolysis and calcium solubilization. Food Res. Int. 125:108525. https://doi.org/10 $.1016 /$ j.foodres.2019.108525.

Langton, M., and A. M. Hermansson. 1992. Fine-stranded and particulate gels of $\beta$-lactoglobulin and whey protein at varying pH. Food Hydrocoll. 5:523-539. https://doi.org/10.1016/S0268 $-005 X(09) 80122-7$.

Lucey, J. A., M. E. Johnson, and D. S. Horne. 2003. Invited review: Perspectives on the basis of the rheology and texture properties of cheese. J. Dairy Sci. 86:2725-2743. https://doi.org/10.3168/jds .S0022-0302(03)73869-7.

Mahajan, D., Z. F. Bhat, and S. Kumar. 2015. Pomegranate (Punica granatum) rind extract as a novel preservative in cheese. Food Biosci. 12:47-53. https://doi.org/10.1016/j.fbio.2015.07.005.

Manzo, C., R. Pizzano, and F. Addeo. 2008. Detection of pH 4.6 insoluble $\beta$-lactoglobulin in heat-treated milk and mozzarella cheese. J. Agric. Food Chem. 56:7929-7933. https://doi.org/10.1021/ jf801190t.

Mucchetti, G., A. Pugliese, and M. Paciulli. 2017. Characteristics of some important Italian cheeses. Page 1-34 in Mediterranean Foods: Composition and Processing. R. M. S. da Cruz and. M. C. Vieira, ed. CRC Press, New York, NY.

Muliawan, E. B., and S. G. Hatzikiriakos. 2007. Rheology of mozzarella cheese. Int. Dairy J. 17:1063-1072. https://doi.org/10.1016/ j.idairyj.2007.01.003.

Needs, E. C. 1992. Effects of long-term deep-freeze storage on the condition of the fat in raw sheep's milk. J. Dairy Res. 59:49-55. https://doi.org/10.1017/S0022029900030235.

Nielsen, S. D., S. Purup, and L. B. Larsen. 2019. Effect of casein hydrolysates on intestinal cell migration and their peptide profiles by LC-ESI/MS/MS. Foods 8:91. https://doi.org/10.3390/ foods 8030091 .

Nielsen, S. D., D. Zhao, T. T. Le, V. Rauh, J. Sørensen, H. J. Andersen, and L. B. Larsen. 2018. Proteolytic side-activity of lactase preparations. Int. Dairy J. 78:159-168. https://doi.org/10.1016/j .idairyj.2017.12.001.

Park, Y. W., P. D. Gerard, and M. A. Drake. 2006. Impact of frozen storage on flavor of caprine milk cheeses. J. Sens. Stud. 21:654663. https://doi.org/10.1111/j.1745-459X.2006.00089.x.

Pastorino, A. J., R. I. Dave, C. J. Oberg, and D. J. McMahon. 2002. Temperature effect on structure-opacity relationships of nonfat mozzarella cheese. J. Dairy Sci. 85:2106-2113. https://doi.org/10 .3168/jds.S0022-0302(02)74288-4.

Petrella, G., S. Pati, R. Gagliardi, A. Rizzuti, P. Mastrorilli, B. la Gatta, and A. Di Luccia. 2015. Study of proteolysis in river buffalo mozzarella cheese using a proteomics approach. J. Dairy Sci. 98:7560-7572. https://doi.org/10.3168/jds.2015-9732.

Rauh, V. 2014. Impact of plasmin activity on the shelf life and stability of UHT milk. PhD thesis. Aarhus University, Aarhus, Denmark.

Rauh, V. M., L. B. Johansen, R. Ipsen, M. Paulsson, L. B. Larsen, and M. Hammershøj. 2014. Plasmin activity in UHT milk: Relationship between proteolysis, age gelation, and bitterness. J. Agric. Food Chem. 62:6852-6860. https://doi.org/10.1021/jf502088u. 
Ribero, G. G., A. C. Rubiolo, and S. E. Zorrilla. 2007. Influence of immersion freezing in $\mathrm{NaCl}$ solutions and of frozen storage on the viscoelastic behavior of mozzarella cheese. J. Food Sci. 72:E301-307. https://doi.org/10.1111/j.1750-3841.2007.00373.x.

Ribero, G. G., A. C. Rubiolo, and S. E. Zorrilla. 2009. Microstructure of Mozzarella cheese as affected by the immersion freezing in $\mathrm{NaCl}$ solutions and by the frozen storage. J. Food Eng. 91:516-520. https://doi.org/10.1016/j.jfoodeng.2008.09.029.

Sánchez-Macías, D., M. Fresno, I. Moreno-Indias, N. Castro, A. Morales-delaNuez, S. Alvarez, and A. Argüello. 2010. Physicochemical analysis of full-fat, reduced-fat, and low-fat artisan-style goat cheese. J. Dairy Sci. 93:3950-3956. https://doi.org/10.3168/jds .2010-3193.

Schmidt, S. J. 2007. Water mobility in foods. Pages 47-108 in Water Activity in Foods. G. V. Barbosa-Canovas, A. J. Fontana, S. J. Schmidt, and T. P. Labuza, ed. Blackwell Publishing Ltd., Oxford, UK.

Sharma, P., P. A. Munro, T. T. Dessev, and P. G. Wiles. 2016. Shear work induced changes in the viscoelastic properties of model mozzarella cheese. Int. Dairy J. 56:108-118. https://doi.org/10.1016/ j.idairyj.2016.01.010.

Sharma Khanal, B. K., C. Budiman, M. P. Hodson, M. R. R. Plan, S. Prakash, B. Bhandari, and N. Bansal. 2019. Physico-chemical and biochemical properties of low fat cheddar cheese made from micron to nano sized milk fat emulsions. J. Food Eng. 242:94-105. https:/ /doi.org/10.1016/j.jfoodeng.2018.08.019.

Somma, A., P. Ferranti, F. Addeo, R. Mauriello, and L. Chianese. 2008. Peptidomic approach based on combined capillary isoelectric focusing and mass spectrometry for the characterization of the plasmin primary products from bovine and water buffalo $\beta$-casein. J. Chromatogr. A 1192:294-300. https://doi.org/10.1016/j.chroma .2008.03.051.

Sousa, M. J., Y. Ardö, and P. L. H. McSweeney. 2001. Advances in the study of proteolysis during cheese ripening. Int. Dairy J. 11:327345. https://doi.org/10.1016/S0958-6946(01)00062-0.

Steffe, J. F. 1996. Rheological Methods in Food Process Engineering. Freeman Press, East Lansing, MI.

Tejada, L., R. Gómez, M. Vioque, E. Sánchez, C. Mata, and J. Fernández-Salguero. 2000. Effect of freezing and frozen storage on the sensorial characteristics of Los Pedroches, a Spanish ewe cheese. J. Sens. Stud. 15:251-262. https://doi.org/10.1111/j.1745-459X.2000 .tb00270.x.

Tribst, A. A. L., L. T. P. Falcade, N. S. Carvalho, M. Cristianini, B. R. C. Leite Júnior, and M. M. de Oliveira. 2020. Using physical processes to improve physicochemical and structural characteristics of fresh and frozen/thawed sheep milk. Innov. Food Sci. Emerg. Technol. 59:102247. https://doi.org/10.1016/j.ifset.2019.102247.

Tribst, A. A. L., L. T. P. Falcade, L. R. Ribeiro, B. R. C. Leite Júnior, and M. M. de Oliveira. 2019. Impact of extended refrigerated storage and freezing/thawing storage combination on physicochemical and microstructural characteristics of raw whole and skimmed sheep milk. Int. Dairy J. 94:29-37. https://doi.org/10 .1016/j.idairyj.2019.02.013.

Trobetas, A., A. Badeka, and M. G. Kontominas. 2008. Light-induced changes in grated Graviera hard cheese packaged under modified atmospheres. Int. Dairy J. 18:1133-1139. https://doi.org/10.1016/ j.idairyj.2008.06.002.

Troller, J. A., and J. H. B. Christian. 1978. Water Activity and Food. Academic Press Inc., New York, NY.

Verdini, R. A., S. E. Zorrilla, and A. C. Rubiolo. 2005. Effects of the freezing process on proteolysis during the ripening of Port Salut Argentino cheeses. Int. Dairy J. 15:363-370. https://doi.org/10 .1016/j.idairyj.2004.08.002.

Voutsinas, L. P., M. C. Katsiari, C. P. Pappas, and H. Mallatou. 1995a. Production of brined soft cheese from frozen ultrafiltered sheep's milk. Part 2: Compositional, physicochemical, microbiological and organoleptic properties of cheese. Food Chem. 52:235-247. https:/ /doi.org/10.1016/0308-8146(95)92818-5.

Voutsinas, L. P., M. C. Katsiari, C. P. Pappas, and H. Mallatou. 1995b. Production of brined soft cheese from frozen ultrafiltered sheep's milk. Part 1: Physicochemical, microbiological and physical stability properties of concentrates. Food Chem. 52:227-233. https://doi.org/10.1016/0308-8146(95)92817-4.

Zambrini, A. V., and M. Bernardi. 2017. A process for preparing mozzarella cheese from curd portions individually deep frozen by IQF technique. Pat. no. WO2017109745A1. Assignee: Granarolo S.P.A., Bologna, Italy.

Zhang, C., E. Bijl, and K. Hettinga. 2018. Destabilization of UHT milk by protease AprX from Pseudomonas fluorescens and plasmin. Food Chem. 263:127-134. https://doi.org/10.1016/j.foodchem .2018.04.128.

\section{ORCIDS}

Marcello Alinovi ๑ https://orcid.org/0000-0003-1757-3537

Lars Wiking (ํ) https://orcid.org/0000-0002-1601-2933

Milena Corredig (1) https://orcid.org/0000-0002-9036-8866

Germano Mucchetti $\odot$ https://orcid.org/0000-0001-8243-6091 